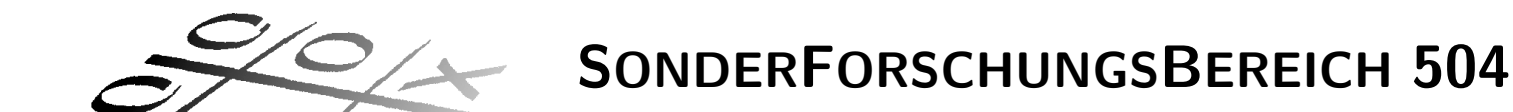

Rationalitätskonzepte,

Entscheidungsverhalten und

ökonomische Modellierung

No. $07-46$

False Consensus and the Role of Ambiguity in

Predictions of Others Risky Preferences

Sina Borgsen*

and Martin Weber**

June 2007

Financial support from the Deutsche Forschungsgemeinschaft, SFB 504, at the University of Mannheim, is gratefully acknowledged.

*Lehrstuhl für ABWL, Finanzwirtschaft, insbesondere Bankbetriebslehre, email: borgsen@bank.bwl.uni-mannheim.de

**Lehrstuhl für ABWL, Finanzwirtschaft, insb. Bankbetriebslehre, email: weber@bank.bwl.unimannheim.de

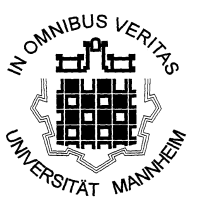

Universität Mannheim

L 13,15

68131 Mannheim 


\title{
False Consensus and the Role of Ambiguity in Predictions of Others’ Risk Preferences
}

\author{
Sina Borgsen and Martin Weber
}

January 2008

\begin{abstract}
Already in the 1930ies psychologists mentioned the tendency of people to see the self as the center of social judgment. This leads to egocentrically biased judgments when assessing others' behavior.

Since the first demonstration of this social projection bias in a study by Ross, Greene, and House (1977) a lot of studies followed. They show the effect in different contexts and the false consensus effect became a widely accepted phenomenon.

In this paper we analyze the false consensus effect in a financial context. In two studies, we use simple lottery questions and ask subjects to state certainty equivalents for the own person and also to predict the average certainty equivalent of other participants. We find a strong correlation between the own judgment and the prediction of others' judgments. As we use 50/50-lotteries and in addition ambiguous probabilities in our studies, we extend the scope of Gilovich (1990) to financial decisions. The false consensus effect is stronger in situations with ambiguity. We also asked participants to give an interval for the certainty equivalents, i.e. a lower bound that they think is not fallen short by more than $5 \%$ of the participants and also an upper bound which is not exceeded by more than $5 \%$. We find that people strongly underestimate the variation in others' risk preferences.
\end{abstract}

Keywords: Risk Attitude, Ambiguity, False Consensus Effect, Prediction Error

JEL Classification Code: G1, D8

\footnotetext{
* Sina Borgsen is from the Lehrstuhl für Bankbetriebslehre, Universität Mannheim, L 5, 2, 68131 Mannheim. EMail: borgsen@bank.BWL.uni-mannheim.de. Martin Weber is from the Lehrstuhl für Bankbetriebslehre, Universität Mannheim, L 5, 2, 68131 Mannheim and CEPR, London. E-Mail: weber@bank.BWL.uni-mannheim.de. We would like to thank seminar participants at the University of Mannheim and members of the ECRP-project Decision Making: “Exploiting” bounded rationality for valuable comments and insights. Financial support from the Deutsche Forschungsgemeinschaft is gratefully acknowledged.
} 


\section{Introduction}

In the 1930ies psychologists mentioned the tendency of people to see the self as the center of social judgment. This leads to egocentrically biased judgments when people are asked to predict the behavior of other people. Ross, Greene, and House (1977) were the first to demonstrate this social projection bias. They find an overall tendency of people to overestimate one's similarity to attitudes, behaviors, and personality traits of other person. People readily think their own opinions, beliefs and predictions to be more prevalent in the general public than they really are. To show this “false consensus effect” Ross, Greene, and House used hypothetical questionnaire studies and they also confronted subjects with real conflict situations. For example, students were asked to carry a sandwich board sign saying "Eat at Joe's" and should predict how many of their fellows would accept or refuse to carry the board.. They find evidence for a false consensus effect in hypothetical questionnaires as well as in real conflict situations. People see their own behavioral choices and judgments as relatively common and appropriate to a specific situation while alternative responses are considered to be uncommon, deviant and inappropriate. In various follow-up studies Ross et al. find the false consensus effect to be especially strong in political expectations, personal traits and views and personal problems.

After 1977 a lot of other studies followed showing the false consensus effect in different contexts and it became a widely accepted phenomenon. Mullen et al. (1985) employ a metaanalysis of 115 hypothesis tests. Their results show that the false consensus is a very stable effect. It could be demonstrated in behaviors, e.g. people watching TV or playing tennis think this behavior is more common than people with other hobbies, in decisions (e.g. eating ham or egg for breakfast, painting a room blue or yellow), in opinions (e.g. political statements, women's rights). Moreover the effect was found in evaluations (e.g. thinking to die before the age of 70, thinking to be better off in later life than the own parents) and also in characteristics (e.g. shy people think this characteristic is more widespread than it actually is).

Marks and Miller (1987) present an empirical and theoretical review of ten years of research on the false consensus effect. Their goal was to summarize possible explanations for the effect. Therefore they present four general theoretical perspectives. The first perspective explains the bias with a selective exposure of similar others. People associate with other people who are similar rather than dissimilar to themselves. This leads to a biased and restricted sample of information. The second explanatory approach stresses salience and focus of attention. People tend to put their focus of attention on their preferred position and this act of en- 
gaging makes the position to be more salient than it really might be. The third approach emphasizes the tendency of people to attribute the cause of their own behavior to situational (in contrast to dispositional) forces. Thus, they conclude others to behave alike in similar contexts. Finally, the fourth explanation assumes a motivational explanation. The overestimation of similarity between the own and other persons may have a functional value, e.g. to maintain self-esteem. Marks and Miller were not able to identify one approach that causes the effect but they find evidence for each of the four theoretical perspectives.

Several studies attribute the false consensus bias to an insufficient adjustment form the anchor of th own perspective. ${ }^{1}$. They suggest that people adopt others' perspectives by using their own perspective as an initial anchor and subsequently adjust for differences between themselves and others. ${ }^{2}$ As these adjustments tend to be insufficient they give rise to egocentric bias.

Gilovich (1990) shows that the false consensus effect is higher in situation with a greater latitude for subjective construal. Divergence of opinion can not only stem from differences in the “judgment of the object” but may also be due to differences in the “object of judgment”. For example, the question “Are you competitive?” allows a higher diversity in interpretation compared to “Are you a first-born or a later-born child?”. Gilovich studies the different issues originally reported in Ross, Greene, and House (1977) and finds a positive correlation between latitude for construal and the size of the false consensus effect. Moreover he performs a study where two versions of the same choice problem were given to subjects, one a more specified version of the other. The participants who are asked to choose and to give a consensus estimate between aqua and tan, for example, exhibit a higher effect than those who decide between two specific swatches of two colors.

Despite the high number of studies analyzing the false consensus effect there is up to our knowledge little about the effect in financial decisions.

Hsee and Weber (1997) find a general prediction error in predictions of others' risky choices. They used 50/50-lotteries and participants had to chose between the lotteries and sure options and in addition they had to predict the choice concerning the same lottery of another subject. The other subject was described in three different ways: as the average American, the average student on campus and as the person sitting next to the participant in the classroom. Hsee and Weber find that the risk preference of the average American and the average student on campus is overestimated in the sense that the prediction is not risk averse enough. This prediction

\footnotetext{
${ }^{1}$ See e.g. Gilovich et al. (1998, 2000), Nickerson (1999) or Epley et al. (2004).

2 See Tversky/Kahnemann (1974) for a description of the anchoring and adjustment heuristic.
} 
error vanishes if the other person becomes very concrete, i.e. if participants are asked to predict the preferences of the person sitting next to them in the room. In this situation there is no overall prediction error.

In an experiment by Engelmann and Stroebel (2004) subjects had to choose whether all four members in their group play a lottery or not and at the same time estimate how many of the subjects in other groups would chose to play the lottery. They find that without any additional information the false consensus effect appears. If information about choices in the own group is explicitly provided, the false consensus effect disappears in the estimation of the other groups. However if the information about the own group is only implicitly provided (in form of payoffs for subjects) the false consensus effect in predicting other groups' behavior again reappears.

Faro and Rottenstreich (2006) did another study of the accuracy of people's predictions of others' risky choices. Like Hsee and Weber they use financial lottery questions but with different probabilities to construct choices in which people typically choose more risk averse or more risk seeking. On the basis of the fourfold pattern of Tversky and Kahneman (1986) they expected risk seeking for a lottery with a small winning probability (0.001) in the gain domain and risk aversion for a high probability (0.99). In the domain of losses they expected risk aversion for the small probability prospect and risk seeking for the large probability loss. In the prediction condition participants are asked to indicate the certainty equivalent of a randomly selected University of Chicago MBA student. They detect a systematic inaccuracy, the predictions of others' choices are too regressive, meaning that predicted certainty equivalents are closer to risk neutrality than they actually are. When people tend to be risk seeking in a situation, they also predict that others are risk seeking but substantially less so. Vice versa, when they tend to be risk averse the prediction of others is less risk averse.

Roszkowski and Grable (2005) study real financial advisors' estimates of risk tolerance of their clients. Advisors were graduates of The American College‘s Master's in Financial Services program. Each advisor was asked to pick two of his clients and all answered a risk tolerance questionnaire developed by the college. Own risk tolerance was measured on a sevenpoint scale and the client's risk tolerance was measured on a ten-point scale. They do not find a positive correlation between own risk tolerance and estimated risk tolerance of the clients.

With this paper we want to contribute to the literature dealing with the predictions of others' risky choices in financial decisions. We are interested in the prediction for a representative (average) individual. This task is quite common in reality. A fund manager has to decide on 
behalf of many investors. A bank has to decide about the variety of offered products. A doctor has to think about the best risky medical treatment for the average patient.

In accordance to Hsee/Weber and Faro/Rottenstreich we hypothesize to find an overall prediction bias in the sense that people overestimate the risk tolerance of others. As we analyze lotteries in the gain domain we expect risk averse decisions for the own person. We hypothesize to find a prediction error in the sense that we expect inadequate high certainty equivalents when participants are asked to predict others' preferences. In addition to former studies, we also use ambiguous probabilities, thus we extend the scope of Gilovich (1990) to financial decisions. Ambiguity is omnipresent in financial decisions, think of the future development of a stock price. Predicting behavior for decision making under ambiguity implies even more uncertainty and therefore provides latitude for construal. We hypothesize to find a stronger prediction error in ambiguous predictions.

Furthermore, as the aggregated prediction of all participants reveals no information about the accuracy of the individual predictions we also want to go beyond the average analysis and also look at the individual predictions. We do not expect people to be able to abstract from their own preferences and we hypothesize to find egocentrically biased predictions, i.e. a false consensus effect in the prediction of others' risky financial choices. We test whether the more risk seeking people tend to predict others to be more risk seeking as well and whether the more risk averse people predict others to be more risk averse. According to Gilovich we hypothesize to find a stronger false consensus effect in the ambiguous situations that are not as clearly specified as the 50/50 lottery problems.

\section{Methodology}

We conducted a written questionnaire (Study 1) as well as a computer based questionnaire in our experimental lab. Participants in the written questionnaire were 84 students from the University of Mannheim attending the graduate course in banking. 23 female and 61 male students, between 19 and 31 years old, answered the questions. In the questionnaire we use a within subject design. Participants first state their own certainty equivalents and afterwards predict the average choice of all participants. They were asked to consider hypothetical lottery questions. Lotteries were a fifty-fifty chance of winning 100 or 0 and a fifty-fifty chance of winning 200 or 50. The same outcomes were used for the ambiguity lotteries where subjects had no information about the probabilities except being between 0 and $100 \%$. 
To display probabilities we used the classical illustration of an urn containing white and yellow balls. As an example Figure 1 shows the first question of the questionnaire (the whole questionnaire is displayed in Appendix A). The instructions read as follows: The following lottery either pays $100 €$ or $0 €$. Imagine an urn containing 100 balls, 50 of them are yellow and 50 of them are white. One ball is drawn, if it is yellow the lottery pays $100 €$, if it is white the lottery pays $0 €$. All students answered the same questionnaire. First they were asked about their own certainty equivalent and subsequently for their prediction of the certainty equivalent of the average other participant. The second question shows the same lottery but with ambiguous probabilities. Again students should give their own certainty equivalent first and afterwards predict the average choice of the other participants. The instructions in this case are as follows: The following lottery either pays $100 €$ or $0 €$. Imagine an urn containing 100 balls. The balls are of yellow and white color, but the proportions are unknown. One ball is drawn, if it is yellow the lottery pays $100 €$, if it is white the lottery pays $0 €$. Students did the questionnaire in class during an exercise session. To motivate students to participate we randomly drew 5 questionnaires and paid $10 €$ to the prescriptive participant. Camerer and Hogarth (1999) show that incentives sometimes improve performance but often they do not. Moreover we know from our course evaluations that students enjoy participating in experiments and questionnaires during the course.

\section{Figure 1: Extract from the written questionnaire, 50/50-lottery $(100,0)$.}

The following lottery either pays $\mathbf{1 0 0} €$ or $\mathbf{0} €$. Imagine an urn containing $\mathbf{1 0 0}$ balls, 50 of them are yellow and $\mathbf{5 0}$ of them are white. One ball is drawn, if it is yellow the lottery pays $1000 €$, if it is white the lottery pays $0 €$.

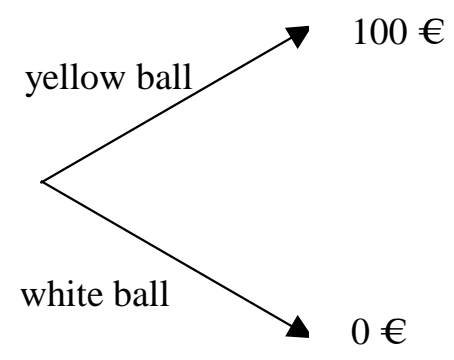

Please state for which amount that you would receive for sure you would be indifferent between receiving the sure amount and playing the lottery

What do you think, for which amount the participants in this questionnaire (thus students attending the exercise course in Banking) are on average indifferent between receiving the sure amount and playing the lottery? 
Participants in the lab were 199 graduate and undergraduate students from the University of Mannheim from various schools. 75 of them were female and 124 male, between 18 and 35 years old. Participants were assigned randomly to two different groups to allow a between subject design. Thus we can control for ordering effects. One group (group self) states own certainty equivalents in the beginning whereas another group predicts the average choice of all participants (group other). In addition the group self afterwards was asked to predict others' preferences and the group other was asked to state own preferences but they did not know this in advance when answering the first questions. Lotteries in the lab were a fifty-fifty chance of winning 1000 or 0 , a fifty-fifty chance of winning 200 or 0 and a fifty-fifty chance of winning 50 or 0 . Again, the same outcomes were used for the ambiguous lotteries. ${ }^{3}$. Figure 2 shows a screenshot of the first 50/50-lottery question in the group self.

\section{Figure 2: Screenshot from the computer based questionnaire,} 50/50-lottery $(1000,0)$.

\section{Question 1:}

The following lottery either pays $1000 €$ or $0 €$. Imagine an urn containing $\mathbf{1 0 0}$ balls, $\mathbf{5 0}$ of them are yellow and $\mathbf{5 0}$ of them are white. One ball is drawn, if it is yellow the lottery pays $1000 €$, if it is white the lottery pays $0 €$

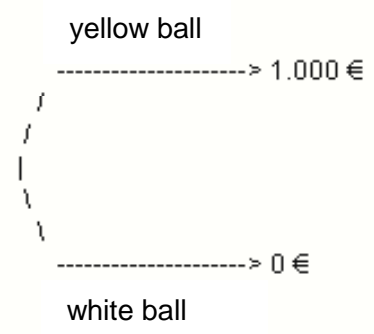

Please state for which amount that you would receive for sure you would be indifferent between receiving the sure amount and playing the lottery.

In the treatment other in the lab, we also asked for an interval. Participants were asked to state a lower bound of the certainty equivalent that they think is not fallen short by more than $5 \%$ and also an upper bound which is not exceeded by more than $5 \%$ of the participants. Students received a flat payment of 5 Euros for their participation. We decided to have a flat payment

\footnotetext{
${ }^{3}$ To conduct the computer based questionnaire we used the software z-Tree (Zurich Toolbox for Readymade Economic Experiments).
} 
in order to have the same incentive structure in the treatments self and other. Moreover, as stated above we do not think that payment is crucial.

\section{Results and Discussion}

\subsection{Analysis of average effects}

Descriptive statistics of the questionnaire results are shown in Table 1. People on average decide risk averse and they also show ambiguity aversion. Certainty equivalents are lower than expected values of the lotteries and the certainty equivalents belonging to the lotteries with unknown probabilities are still lower than those with fifty-fifty-probabilities (for an explanation of ambiguity see Ellsberg, 1961).

At first we want to test whether there is an effect on the average level. There is a clear standard for assessing the accuracy or inaccuracy of predictions: in case of an accurate prediction the mean predicted certainty equivalent would be equal to the mean stated own certainty equivalent.

Our data from the studies follows somewhat skewed distributions. Therefore we will use nonparametric tests of statistical significance. Looking at the questionnaire results in Table 1 there is no overall prediction bias as in Hsee and Weber (1997) or in Faro and Rottenstreich (2006). Considering the mean (median) people do not seem to make a difference between stating own and evaluating others' certainty equivalents. The Wilcoxon signed rank test shows that there are no significant differences between the certainty equivalents for the own person and the predicted ones for the other participants. On average people do not overestimate the willingness of others to take risks or predict them to be closer to risk neutrality than they actually are. Our results may be compared with the third treatment in Hsee and Weber where participants were asked to predict preferences of the person sitting next to them in class. With this very concrete description of the other person the prediction bias disappeared. We conducted our questionnaire during an exercise class and asked the students for their own certainty equivalents and afterwards to predict the average choice of the participants. As the students were able to look around in the room at the other participants it is likely that we find the same concreteness effect as in Hsee and Weber. 
Table 1: Descriptive statistics (written questionnaire),

The table shows descriptive statistics (mean, median, standard deviation, minimum value, maximum value) of the certainty equivalents. The upper part presents own preferences, the middle part predictions of others' preferences. The lower part compares own and predicted preferences.

\begin{tabular}{l|rrrr}
\begin{tabular}{l|rrr} 
lottery \\
prob.
\end{tabular} & $\mathbf{( 1 0 0 , 0 )}$ & $\mathbf{( 2 0 0 , 5 0 )}$ & $\mathbf{( 1 0 0 , 0 )}$ & $\mathbf{( 2 0 0 , 5 0 )}$ \\
ce self & $\mathbf{5 0 / 5 0}$ & $\mathbf{5 0 / 5 0}$ & $\mathbf{?}$ ? & ?/? \\
\hline mean & self & self & self & self \\
median & 44.46 & 110.19 & 34.33 & 90.46 \\
sd & 50.00 & 113.50 & 30.00 & 90.00 \\
min & 12.94 & 23.82 & 21.40 & 31.93 \\
max & 20.00 & 50.00 & 0.00 & 20.00 \\
& 80.00 & 170.00 & 100.00 & 200.00 \\
ce other & other & other & other & other \\
\hline mean & 42.55 & 106.82 & 35.12 & 90.06 \\
median & 45.00 & 106.00 & 30.00 & 90.00 \\
sd & 11.86 & 23.29 & 18.97 & 28.03 \\
min & 1.00 & 50.00 & 1.00 & 20.00 \\
max & 70.00 & 150.00 & 100.00 & 150.00 \\
& & & & \\
Wilcoxon & not sig & not sig & not sig & not sig \\
ce self $>$ ce other & & & & \\
ce self < ce other & 34 & 25 & 29 & 34 \\
ce self $=$ ce other & 27 & 30 & 26 & 25 \\
& 23 & 29 & 29 & 25
\end{tabular}

Table 2: Descriptive statistics (computer based questionnaire),

The table shows descriptive statistics (mean, median, standard deviation, minimum value, maximum value) of the certainty equivalents. The upper part presents own preferences, the middle part predictions of others' preferences. The lower part compares own and predicted preferences.

\begin{tabular}{|c|c|c|c|c|c|c|}
\hline lottery & $(1000,0)$ & $(200,0)$ & $(50,0)$ & $(1000,0)$ & $(200,0)$ & $(50,0)$ \\
\hline prob. & $50 / 50$ & $50 / 50$ & $50 / 50$ & ?/? & ?/? & ?/? \\
\hline ce self & self & self & self & self & self & self \\
\hline mean & 440.33 & 93.37 & 25.99 & 362.48 & 81.61 & 23.00 \\
\hline median & 500.00 & 100.00 & 25.00 & 350.00 & 80.00 & 24.00 \\
\hline sd & 186.62 & 33.88 & 8.38 & 229.29 & 44.89 & 11.00 \\
\hline $\min$ & 0.00 & 0.00 & 5.00 & 0.00 & 1.00 & 0.10 \\
\hline $\max$ & 1000.00 & 200.00 & 50.00 & 1000.00 & 200.00 & 50.00 \\
\hline ce other & other & other & other & other & other & other \\
\hline mean & 424.34 & 93.13 & 24.89 & 390.35 & 81.44 & 22.34 \\
\hline median & 500.00 & 100.00 & 25.00 & 400.00 & 80.00 & 20.00 \\
\hline sd & 164.70 & 28.19 & 7.64 & 226.99 & 39.69 & 9.79 \\
\hline $\min$ & 20.00 & 10.00 & 3.00 & 10.00 & 2.00 & 1.00 \\
\hline $\max$ & 1000.00 & 150.00 & 50.00 & 1000.00 & 200.00 & 50.00 \\
\hline Wilcoxon & not sig & not sig & $p<0.01$ & not sig & not sig & not sig \\
\hline ce self > ce other & 66 & 64 & 75 & 69 & 75 & 77 \\
\hline ce self $<$ ce other & 62 & 62 & 41 & 79 & 77 & 60 \\
\hline ce self $=$ ce other & 71 & 73 & 83 & 51 & 47 & 62 \\
\hline
\end{tabular}


Table 2 shows similar results for the lottery questions in the lab. As we do not find strong ordering effects (see appendix B) we used all 199 observations regardless of whether they stated their own certainty equivalents first or whether they predicted those of others first. Only one out of six difference between self and others is significant. For the 50/50-lottery $(50,0)$ the participants are more risk seeking for the own person than for others. This is in line with Faro and Rottenstreich (2006) who find that people are closer to risk neutrality when evaluating certainty equivalents of others compared to their own. The other five differences are like the questionnaire differences not significant. Hence we cannot find evidence for an effect on the aggregated level. Again this result is comparable to the third treatment of Hsee and Weber (1997). During the experiment students were sitting in the lab together with other participants. Up to 20 students did the experiment at the same time. So like in the questionnaire situation they were able to look around and thereby get a concrete view of the other participants.

\subsection{Individual level analysis}

So far we found that the average predicted certainty equivalent is not significantly different from the average own certainty equivalent. But does this necessarily mean that individual people are also able to make a good prediction?

The financial analyst Paul Johnson (2004) found an interesting effect. From 1995 to 1999, he asked his students, studying at the Graduate School of Business, Columbia University, to predict the winners in 12 Oscar categories. His results over the years have been pretty consistent, in all but one year, the consensus has never lost to an individual student. For instance, in 1997 (a year in which 125 students voted) the average student was right on only 4.83 predictions, but the consensus got 11 out of 12 correct. So the consensus seems to be a better predictor than an individual prediction, as the prediction mistakes cancel each other out.

In the following we go beyond the aggregated analysis and also look at individual predictions. We hypothesize to find a false consensus effect on the individual level. The more risk averse a person is herself the more risk averse she evaluates others and, vice versa, a more risk seeking person sees others also as more risk seeking. To gain first insights we split the data in two halves, the relatively more risk averse whose certainty equivalent is smaller than the median and the relatively more risk seeking people who have a certainty equivalent greater than the median. 
Table 3: Splitting results,

Mean and median certainty equivalents within different groups (Questionnaire), pvalues state the probability that the predictions of the two subgroups are the same.

\begin{tabular}{|c|c|c|c|c|c|c|c|c|c|c|}
\hline & & \multicolumn{2}{|c|}{ |all subjects } & \multicolumn{3}{|c|}{\begin{tabular}{|} 
more risk averse subjects \\
(ce self < median self)
\end{tabular}} & \multicolumn{3}{|c|}{$\begin{array}{l}\text { more risk seeking subjects } \\
\text { (ce self }>\text { median self) }\end{array}$} & \multirow[b]{2}{*}{ p-value } \\
\hline \multicolumn{2}{|c|}{ lottery $(100,0)$} & self & other & self & other & obs & self & other & obs & \\
\hline \multirow[t]{2}{*}{$50 / 50$} & mean & 44.46 & 42.55 & 33.73 & 37.33 & 40 & 63.29 & 52.50 & 14 & $<0.01$ \\
\hline & median & 50.00 & 45.00 & 35.00 & 40.00 & & 60.00 & 50.00 & & \\
\hline \multirow[t]{2}{*}{$? / ?$} & mean & 34.33 & 35.12 & 13.46 & 21.75 & 28 & 52.97 & 48.17 & 36 & $<0.01$ \\
\hline & median & 30.00 & 30.00 & 10.00 & 15.00 & & 50.00 & 50.00 & & \\
\hline \multicolumn{11}{|c|}{ lottery $(200,50)$} \\
\hline \multirow[t]{2}{*}{$50 / 50$} & mean & 110.19 & 106.82 & 90.88 & 103.02 & 42 & 129.50 & 110.62 & 42 & $<0.06$ \\
\hline & median & 113.50 & 106.00 & 100.00 & 100.00 & & 125.00 & 120.00 & & \\
\hline \multirow[t]{2}{*}{$? / ?$} & mean & 90.46 & 90.06 & 64.35 & 70.43 & 40 & 119.58 & 111.06 & 36 & $<0.01$ \\
\hline & median & 90.00 & 90.00 & 65.00 & 70.00 & & 120.00 & 114.00 & & \\
\hline
\end{tabular}

Table 4: Splitting results,

Mean and median certainty equivalents within different groups (Lab), p-values state the probability that the predictions of the two subgroups are the same.

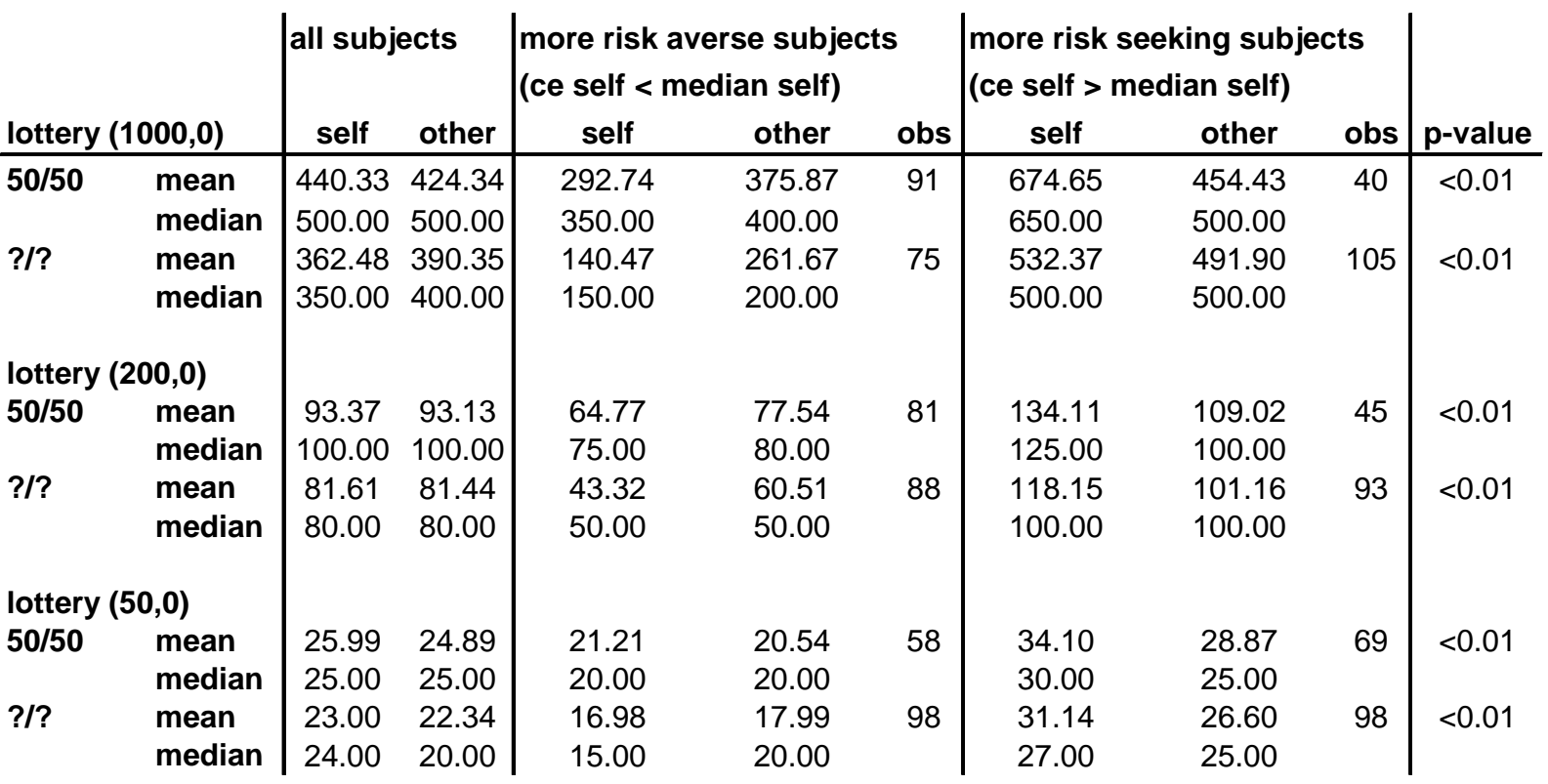

Tables 3 and 4 (Questionnaire and lab results) reveal first evidence for a false consensus effect. First, we perform a median split according to the stated own certainty equivalent. ${ }^{4}$ Thus we get one relatively risk averse subgroup (own certainty equivalent smaller than group median) and one relatively risk seeking subgroup (own certainty equivalent bigger than group median). Second we compare the predicted certainty equivalents for others given by the sub-

\footnotetext{
${ }^{4}$ In Tables 3 and 4 answers equal to the median drop out of the analysis. In some lotteries this is a considerable part, e.g. in the lab experiment when asked for the certainty equivalent for the 50/50-lottery (1000,0), 68 participants gave the median answer $500 €$. Nevertheless, the results remain unchanged if the median observations are added to the relatively more risk averse or to the relatively more risk seeking subgroup (see appendix C).
} 
groups. P-values (Wilcoxon rank-sum tests) ${ }^{5}$ stated in the last column test the hypothesis that the predictions of the two subgroups are the same. For the 50/50 lottery $(100,0)$ the relatively risk averse group states a mean certainty equivalent for others of 37.33 (median 40.00). In contrast the relatively risk seeking group states a mean certainty equivalent of 52.50 (median 50.00). The difference is highly significant at the 1 percent level. This result is very robust, as we also find a significant difference in all of the other 9 lotteries. The relatively more risk averse people also give a more risk averse prediction compared to the risk seeking subgroup.

Despite the significant differences in the predicted certainty equivalents between the subgroups the differences in the own certainty equivalents seem to be still higher. Hence, it seems to be the case that people adjust their own certainty equivalent when asked for a prediction of the average other. We compare the own certainty equivalents with the predicted certainty equivalents within the subgroups. ${ }^{6}$ For example, the relatively risk averse group in the questionnaire states a mean own certainty equivalent for the 50/50-lottery $(100,0)$ of 33.73 (median 35.00) while the mean predicted certainty equivalent is 37.33 (median 40.00). The prediction is significantly higher at the 5 percent level. In all but the ambiguous $(200,50)$ lottery within the risk averse subgroup the prediction is significantly different (at least at the 5 percent level) from the own certainty equivalent. The lab data confirms the questionnaire results. The difference between own and predicted certainty equivalent in the relatively risk seeking subgroup for the ambiguous (1000,0)-lottery is significant at the 5 percent level, all other differences even at the 1 one percent level. So, indeed the more risk averse people estimate others as less risk averse compared to themselves and the more risk seeking predict that others are less risk seeking and both groups are right with the direction of the adjustment.

To test the strength of the adjustment, we performed another test and compare the predictions of the subgroups with the own certainty equivalent of the whole group. ${ }^{7}$ In all but the ambiguous $(200,50)$ lottery of the questionnaire the prediction is significantly different (at least at the 5 percent level). The lab data shows a similar pattern. The prediction of the relatively more risk seeking subgroup for the 50/50-lottery $(1000,0)$ is not significantly different from the own certainty equivalent of the whole group. All other predictions are significantly (at least at

\footnotetext{
${ }^{5}$ We are not able to use the classical test of false consensus Ross, Greene and House (1977) define. This would be a test of the difference between the estimates of consensus for position A made by subjects who hold position A and the estimates of consensus for position A made by subjects who hold position $\mathrm{B}$. As the certainty equivalent is a continuous variable with a lot more than two possible parameter values we have to use other statistics in the following.

${ }^{6}$ P-Values (Wilcoxon signed-rank test) not reported in the table.

${ }^{7} \mathrm{P}$-Values (Wilcoxon rank-sum test) not reported in the table.
} 
the 5 percent level) too low (risk averse subgroup) or too high (risk seeking subgroup). Thus although people adjust their own certainty equivalent in the right direction their adjustment is not strong enough.

Figure 3 shows a plot of own and predicted certainty equivalents of the (100,0)-lottery with 50/50-probabilities and with ambiguous probabilities (for other lotteries see appendix D). In addition to the data points a regression line is added to the Figure. A flat regression line would indicate no false consensus effect at all, i.e. the prediction would be independent from the size of the own certainty equivalent whereas a slope of 1 would indicate a "perfect" false consensus effect, i.e. the prediction would be equal to the own certainty equivalent. Both regression lines in the figure are not as steep as the 45 degree line, indicating that individuals adjust their own certainty equivalent in the right direction for the prediction of others. But still the relatively more risk averse participants tend to predict others as too risk averse and the relatively more risk seeking vice versa (positive slope of the regression lines). For the 50/50probabilities the adjustment is stronger than for the ambiguous probabilities, the regression line is steeper in the latter case suggesting that the own preferences are even more crucial if uncertainty is higher.

Figure 3: Plot of the (100,0)-lottery and regression lines for 50/50- and ?/?-probabilities.

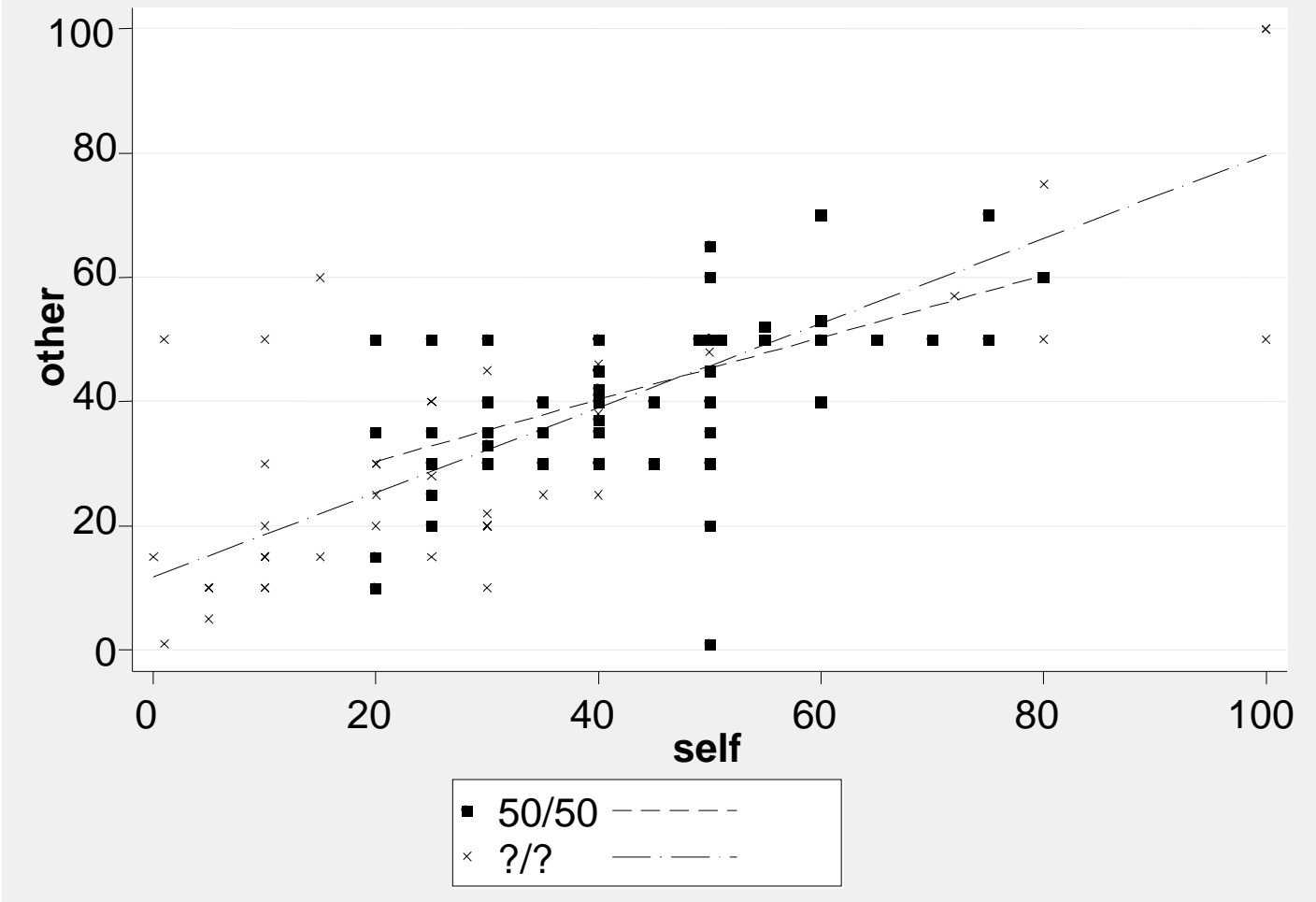


In the following we analyze this effect in more detail. Table 5 shows Pearson correlation coefficients. As expected all correlations are significantly different from 0 at the 1 percent level. ${ }^{8}$ This supports our hypothesis that a false consensus effect is present in financial decisions. The predictions of others' preferences depend strongly on the own preferences.

Furthermore it is noteworthy that correlations between own and predicted certainty equivalent are higher in the case of ambiguous lotteries. For example the correlation in the $(100,0)$ lottery with 50/50-probabilities is 0.5447 , with ambiguous probabilities the correlation increases to 0.7667 . The difference of the correlations with and without ambiguity is significant in all cases (questionnaire as well as lab), p-values are stated in the fourth column. So it seems to be the case that in situations with higher uncertainty (ambiguity) people rely more heavily on their own preference in order to predict certainty equivalents of other people. ${ }^{9}$

Table 5: Correlation coefficients, p-values state the probability that correlations are the same.

\begin{tabular}{l|ccc} 
& Prob. & Correlation & p-value \\
\hline Questionnaire & & & \\
\hline Lottery $(\mathbf{1 0 0 , 0 )}$ & $50 / 50$ & 0.5447 & \\
& $? / ?$ & 0.7667 & $(p<0.05)$ \\
Lottery $(\mathbf{2 0 0 , 5 0 )}$ & $50 / 50$ & 0.2746 & \\
& $? / ?$ & 0.7266 & $(p<0.01)$ \\
& & & \\
\hline Lab & & & \\
\hline Lottery $(\mathbf{1 0 0 0 , 0 )}$ & $50 / 50$ & 0.3212 & \\
& $? / ?$ & 0.5733 & $(p<0.01)$ \\
Lottery (200,0) & $50 / 50$ & 0.4996 & \\
& $? / ?$ & 0.7124 & $(p<0.01)$ \\
Lottery $(\mathbf{5 0 , 0 )}$ & $50 / 50$ & 0.6463 & \\
& $? / ?$ & 0.7522 & $(p<0.10)$
\end{tabular}

Table 6: Regression results (questionnaire): Regression of the predicted certainty equivalent on the own certainty equivalent and control variables. * indicates significance at the ten percent level,** indicates significance at the five percent level, $* * *$ indicates significance at the one percent level.

\begin{tabular}{|c|c|c|c|c|c|c|c|c|}
\hline & \multicolumn{4}{|c|}{ Prediction $(100,0)$} & \multicolumn{4}{|c|}{ Prediction $(200,50)$} \\
\hline & $50 / 50$ & $50 / 50$ & ?/? & ?/? & $50 / 50$ & $50 / 50$ & ?/? & ?/? \\
\hline Gender & & $\begin{array}{l}-0.6233 \\
(-0.25)\end{array}$ & & $\begin{array}{c}-3.4770 \\
(-1.14)\end{array}$ & & $\begin{array}{c}-1.1746 \\
(-0.21)\end{array}$ & & $\begin{array}{l}-9.7995 \\
(-2.09)^{\star \star}\end{array}$ \\
\hline Age & & $\begin{array}{c}0.1022 \\
(0.19)\end{array}$ & & $\begin{array}{c}0.5346 \\
(0.81)\end{array}$ & & $\begin{array}{c}-0.7991 \\
(-0.66)\end{array}$ & & $\begin{array}{l}-.6655 \\
(-0.65)\end{array}$ \\
\hline Own CE & $\begin{array}{c}0.4992 \\
(5.88)^{\star \star \star}\end{array}$ & $\begin{array}{c}0.4966 \\
(5.72)^{\star \star \star}\end{array}$ & $\begin{array}{c}0.6797 \\
(10.81)^{\star \star \star}\end{array}$ & $\begin{array}{c}0.6651 \\
(10.40)^{\star \star \star}\end{array}$ & $\begin{array}{c}0.2685 \\
(2.59)^{\star \star}\end{array}$ & $\begin{array}{c}0.2708 \\
(2.58)^{\star \star}\end{array}$ & $\begin{array}{c}0.6378 \\
(9.58)^{\star \star \star}\end{array}$ & $\begin{array}{r}0.6380 \\
(9.71)^{\star \star \star}\end{array}$ \\
\hline Constant & $\begin{array}{l}20.3532 \\
(5.18)^{\star \star \star} \\
\end{array}$ & $\begin{array}{c}18.4492 \\
-(1.34) \\
\end{array}$ & $\begin{array}{l}11.7823 \\
(4.64)^{\star \star \star}\end{array}$ & $\begin{array}{c}1.8821 \\
(0.12) \\
\end{array}$ & $\begin{array}{l}77.2369 \\
(6.60)^{\star \star \star}\end{array}$ & $\begin{array}{l}97.1545 \\
(3.09)^{\star \star \star}\end{array}$ & $\begin{array}{l}32.3640 \\
(5.07)^{\star \star \star}\end{array}$ & $\begin{array}{l}55.5530 \\
(2.24)^{\star \star}\end{array}$ \\
\hline N & 84 & 84 & 84 & 84 & 84 & 84 & 84 & 84 \\
\hline Adjusted R-squared & 0.2881 & 0.2711 & 0.5828 & 0.5814 & 0.0641 & 0.0469 & 0.5222 & 0.5401 \\
\hline
\end{tabular}

\footnotetext{
${ }^{8}$ We used the stata module cortesti by H. M. Caci. The test is an approximation (to be used when both samples are larger than 10).

${ }^{9}$ Unreported Spearman rank correlation coefficients show similar results.
} 
Table 7: Regression results (lab): Regression of the predicted on the own certainty equivalent and control variables. * indicates significance at the ten percent level,** indicates significance at the five percent level, $* * *$ indicates significance at the one percent level.

\begin{tabular}{|c|c|c|c|c|c|c|c|c|}
\hline & \multicolumn{4}{|c|}{ Prediction $(1000,0)$} & \multicolumn{4}{|c|}{ Prediction $(200,0)$} \\
\hline & $50 / 50$ & $50 / 50$ & ?/? & $? / ?$ & $50 / 50$ & $50 / 50$ & ?/? & $? / ?$ \\
\hline Gender & & $\begin{array}{c}-23.6736 \\
(-0.97)\end{array}$ & & $\begin{array}{c}-8.4845 \\
(-0.29)\end{array}$ & & $\begin{array}{c}-4.6243 \\
(-1.20)\end{array}$ & & $\begin{array}{c}0.0563 \\
(0.01)\end{array}$ \\
\hline Age & & $\begin{array}{c}3.4995 \\
(0.61)\end{array}$ & & $\begin{array}{c}2.4320 \\
(0.35)\end{array}$ & & $\begin{array}{c}0.7963 \\
(0.87)\end{array}$ & & $\begin{array}{l}2.4017 \\
(2.09)^{\star \star}\end{array}$ \\
\hline Semester & & $\begin{array}{c}-0.4594 \\
(-0.09)\end{array}$ & & $\begin{array}{c}-1.7782 \\
(-0.28)\end{array}$ & & $\begin{array}{c}-1.3589 \\
(-1.62)\end{array}$ & & $\begin{array}{c}-1.0644 \\
(-1.02)\end{array}$ \\
\hline Knowledge & & $\begin{array}{c}21.5843 \\
(0.85)\end{array}$ & & $\begin{array}{c}21.1196 \\
(0.69)\end{array}$ & & $\begin{array}{c}0.0604 \\
(0.02)\end{array}$ & & $\begin{array}{c}6.1527 \\
(1.22)\end{array}$ \\
\hline Ordering & & $\begin{array}{c}-14.7702 \\
(-1.10)\end{array}$ & & $\begin{array}{c}-29.5712 \\
(-1.82)^{\star}\end{array}$ & & $\begin{array}{c}-2.4219 \\
(-1.13)\end{array}$ & & $\begin{array}{l}-5.7441 \\
(-2.14)^{\star \star}\end{array}$ \\
\hline Own CE & $\begin{array}{c}0.2835 \\
(4.76)^{\star \star \star}\end{array}$ & $\begin{array}{c}0.2971 \\
(4.89)^{\star \star \star}\end{array}$ & $\begin{array}{c}0.5531 \\
(9.45)^{\star \star \star}\end{array}$ & $\begin{array}{c}0.5664 \\
(9.53)^{\star \star \star}\end{array}$ & $\begin{array}{c}0.3873 \\
(7.38)^{\star \star \star}\end{array}$ & $\begin{array}{c}0.4069 \\
(7.67)^{\star \star \star}\end{array}$ & $\begin{array}{c}0.5361 \\
(10.70)^{\star \star \star}\end{array}$ & $\begin{array}{c}0.5592 \\
(11.12)^{\star \star \star}\end{array}$ \\
\hline Constant & $\begin{array}{c}299.53 \\
(10.52)^{\star \star \star}\end{array}$ & $\begin{array}{r}156.17 \\
(1.17) \\
\end{array}$ & $\begin{array}{c}189.88 \\
(7.57)^{\star \star \star}\end{array}$ & $\begin{array}{c}115.78 \\
(0.73) \\
\end{array}$ & $\begin{array}{c}56.9594 \\
(10.93)^{\star \star \star}\end{array}$ & $\begin{array}{c}40.8753 \\
(1.92)^{\star}\end{array}$ & $\begin{array}{l}37.6950 \\
(8.08)^{\star \star \star}\end{array}$ & $\begin{array}{c}-19.8507 \\
(-0.74) \\
\end{array}$ \\
\hline $\mathbf{N}$ & 199 & 199 & 199 & 199 & 199 & 199 & 199 & 199 \\
\hline Adjusted R-squared & 0.0986 & 0.0932 & 0.3086 & 0.3052 & 0.2126 & 0.2170 & 0.3643 & 0.3793 \\
\hline & & Prediction & $(50,0)$ & & & & & \\
\hline & $50 / 50$ & $50 / 50$ & ?!? & ?/? & & & & \\
\hline Gender & & $\begin{array}{c}-0.6342 \\
(-0.61)\end{array}$ & & $\begin{array}{l}1.7237 \\
(1.47)\end{array}$ & & & & \\
\hline Age & & $\begin{array}{c}0.0307 \\
(0.13)\end{array}$ & & $\begin{array}{c}0.4066 \\
(1.47)\end{array}$ & & & & \\
\hline Semester & & $\begin{array}{c}-0.1553 \\
(-0.70)\end{array}$ & & $\begin{array}{c}-0.4302 \\
(-1.71)\end{array}$ & & & & \\
\hline Knowledge & & $\begin{array}{c}0.2141 \\
(0.20)\end{array}$ & & $\begin{array}{c}1.1281 \\
(0.93)\end{array}$ & & & & \\
\hline Ordering & & $\begin{array}{c}-0.0366 \\
(-0.06)\end{array}$ & & $\begin{array}{c}-0.3649 \\
(-0.56)\end{array}$ & & & & \\
\hline Own CE & $\begin{array}{c}0.4611 \\
(8.23)^{\star \star \star}\end{array}$ & $\begin{array}{c}0.4623 \\
(7.91)^{\star \star \star}\end{array}$ & $\begin{array}{c}0.5647 \\
(11.52)^{\star \star \star}\end{array}$ & $\begin{array}{c}0.5661 \\
(11.44)^{\star \star \star}\end{array}$ & & & & \\
\hline Constant & $\begin{array}{l}12.9057 \\
(8.43)^{\star \star \star}\end{array}$ & $\begin{array}{l}11.9905 \\
(2.16)^{\star \star}\end{array}$ & $\begin{array}{c}9.3514 \\
(7.49)^{\star \star \star}\end{array}$ & $\begin{array}{c}3.3110 \\
(0.52)\end{array}$ & & & & \\
\hline $\mathbf{N}$ & 199 & 199 & 199 & 199 & & & & \\
\hline Adjusted R-squared & 0.2519 & 0.2519 & 0.3994 & 0.4016 & & & & \\
\hline
\end{tabular}

To control for other effects Tables 6 and 7 show regression results of the predicted on the own certainty equivalent and further variables. In the questionnaire (Table 6) we control for gender (dummy: $1=$ male, 0 = female) and age. The results show that predictions are not driven by age (however as we did the studies with student participants we have little variation in age in our dataset), gender is only significant in one regression. Thus the age of the person cannot explain how someone predicts others' preferences. In the ambiguous (200,50)-lottery men predict a smaller certainty equivalent for the average other. This result does not contradict the frequent observation that women are in general more risk averse than men (see e.g. Dohmen et al. (2005)) because this is already included in the variable own certainty equivalent. It may be that men perceive others to be less risk seeking compared to themselves because they consider risk seeking as an admirable characteristic and at the same time they think they are better than others (risk-as-value hypothesis, see Hsee and Weber 1997). In all regressions the 
own certainty equivalent is highly significant. In addition to this the regression coefficient and the R-squares are higher for ambiguous predictions. This supports our hypothesis that the prediction depends on the own preference and that the influence of the own preference is especially strong for ambiguous situations.

Participants in the lab (Table 7) were additionally asked to state their semester and subjective knowledge about financial markets. Moreover, we included a dummy considering ordering (0 = group "self" at the beginning, 1 = group "other" at the beginning). Similar to the questionnaire predictions are not driven by gender. Age is only significant in the (200,0)-lottery with ambiguous probabilities. Financial knowledge (self assessment from $1=$ very good to $6=$ very bad) has no significant effect. Ordering is significant only in 2 cases in the sense that the predicted certainty equivalent is lower if participants first predicted the average certainty equivalent before they were asked for their own certainty equivalent. This result is mostly in line with results stated in appendix B showing that there is no overall ordering effect. Again, the own certainty equivalent is highly significant for all predictions and the coefficients are higher for lotteries with ambiguous probabilities.

Our main results from the regressions can be summarized as follows: We document a highly significant effect of the own certainty equivalent on prediction of others. Moreover, this effects seems to be stronger for ambiguity.

To include the effect of ambiguity in our regression analysis we use combined regressions with data from several lotteries (with and without ambiguity). To aggregate the data in one regression we cannot use the absolute values but need to normalize them. Predictions are normalized by the expected value of the lotteries, so the dependent variable is given by $\underline{\text { predicted certainty equivalent - expected value }}$. Accordingly, the own certainty equivalent as expected value

an independent variable is given by own equivalent - expected value .Thus instead of the abexpected value

solute certainty equivalents we use the relative deviations from the expected value. In addition to the expected values we did the same analysis using the mean stated certainty equivalents instead of the expected values. The results do not change (see Appendix F).

In a first step the 50/50-lotteries and the ambiguous lotteries were aggregated in one regression, respectively. Results are stated in the left parts of Tables 8 (questionnaire) and 9 (lab). For demonstration Figure 4 shows a plot of the normalized data from the questionnaire (see 
Appendix E for the same Figure with the lab data). In every regression (questionnaire and lab) the predicted certainty equivalent is highly significantly driven by the own certainty equivalent. Moreover, the regression coefficient is higher for the ambiguous lotteries.

Looking at the questionnaire results (Table 8, left part) gender yields a significant effect in the regression with the ambiguous lotteries in the sense that men predict the certainty equivalent of others to be smaller. Age has no explanatory power. Combining the lotteries from the lab we find the following significant effects in our control variables. For the 50/50-lotteries men's predictions are lower, a higher semester also leads to a lower prediction. Higher financial knowledge causes a higher prediction and the predicted certainty equivalent is lower if participants first gave a prediction before stating their own certainty equivalent. Age has no significant influence. In the ambiguous case gender and financial knowledge do not have explanatory power. Age and semester have a significant positive influence. The ordering effect is even stronger than in the 50/50 regression. However it is noteworthy that all independent significant variables expect for the own certainty equivalent show only very low regression coefficients. Thus a change in these variables does not have a strong effect on the predicted certainty equivalent. The adjusted R-squared is always higher in ambiguous situations, i.e. a greater part of the prediction can be explained by the explanatory variables, especially by the own certainty equivalent. The false consensus effect seems to be greater in situations with ambiguity.

Figure 4: Plot of the combined lotteries (questionnaire) and regression lines for 50/50and ?/?-probabilities.

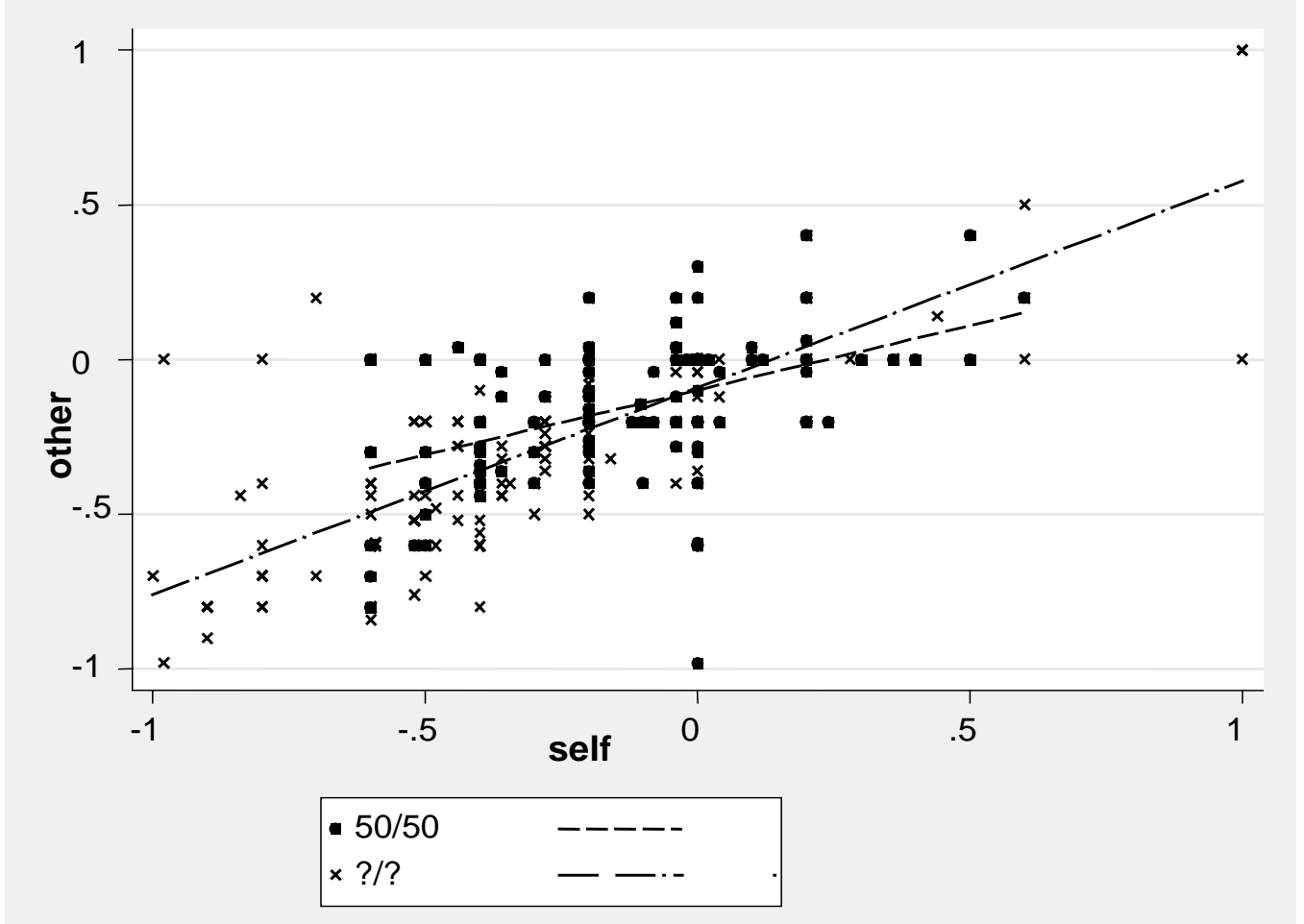


Secondly we aggregate all observations in a single regression and add dummy variables indicating whether ambiguity is involved or not. Results are stated in the right part of Tables 8 and 9.

Table 8: Regression results (questionnaire):

Regression of the predicted certainty equivalent on the own certainty equivalent (normalized by the expected value). Left side: Separate regressions for 2 lotteries with 50/50probabilities and 2 lotteries with ambiguous probabilities. Right side: Regressions with all 4 lotteries.

* indicates significance at the ten percent level,** indicates significance at the five percent level, $* * *$ indicates significance at the one percent level.

\begin{tabular}{|c|c|c|c|c|c|c|c|c|c|}
\hline & \multicolumn{4}{|c|}{ Predicted CE (Quest., each with 2 Lotteries) } & \multirow{2}{*}{\multicolumn{5}{|c|}{ Predicted CE (Questionnaire, each with all 4 Lotteries) }} \\
\hline & $50 / 50$ & $50 / 50$ & ?/? & ?/? & & & & & \\
\hline Gender & & $\begin{array}{c}-0.0166 \\
(-0.50)\end{array}$ & & $\begin{array}{l}-0.0742 \\
(-2.09)^{\star \star}\end{array}$ & & & & & $\begin{array}{c}-0.0139 \\
(-0.78)\end{array}$ \\
\hline Age & & $\begin{array}{c}-0.0022 \\
(-0.31)\end{array}$ & & $\begin{array}{c}0.0026 \\
(0.34)\end{array}$ & & & & & $\begin{array}{l}-0.0018 \\
(-0.46)\end{array}$ \\
\hline Dummy Ambiguity & & & & & & $\begin{array}{c}-0.0341 \\
(-1.50)\end{array}$ & & $\begin{array}{c}0.1335 \\
(7.08)^{\star \star \star}\end{array}$ & $\begin{array}{c}0.1327 \\
(7.01)^{\star \star \star \star}\end{array}$ \\
\hline Own CE * Dummy Ambi & & & & & & & $\begin{array}{c}0.6608 \\
(15.40)^{\star \star \star}\end{array}$ & $\begin{array}{c}0.8224 \\
(17.83)^{\star \star \star}\end{array}$ & $\begin{array}{c}0.8209 \\
(17.63)^{\star \star \star}\end{array}$ \\
\hline Own CE & $\begin{array}{c}0.4178 \\
(6.41)^{\star \star \star}\end{array}$ & $\begin{array}{c}0.4160 \\
(6.34)^{\star \star \star}\end{array}$ & $\begin{array}{c}0.6682 \\
(14.90)^{\star \star \star}\end{array}$ & $\begin{array}{c}0.6582 \\
(14.64)^{\star \star \star}\end{array}$ & $\begin{array}{c}0.6109 \\
(17.23)^{\star \star \star}\end{array}$ & $\begin{array}{c}0.5948 \\
(16.07)^{\star \star \star}\end{array}$ & $\begin{array}{c}0.2352 \\
(6.451)^{\star \star \star}\end{array}$ & $\begin{array}{c}0.2057 \\
(5.99)^{\star \star \star}\end{array}$ & $\begin{array}{c}0.2062 \\
(6.00)^{\star \star \star}\end{array}$ \\
\hline Constant & $\begin{array}{c}-0.0994 \\
(-6.01)^{\star \star \star}\end{array}$ & $\begin{array}{c}-0.0336 \\
(-0.19)\end{array}$ & $\begin{array}{l}-0.0916 \\
(-4.46)^{\star \star \star}\end{array}$ & $\begin{array}{c}-0.1044 \\
(-0.56)\end{array}$ & $\begin{array}{c}-0.0928 \\
(-7.07)^{\star \star \star}\end{array}$ & $\begin{array}{l}-0.0791 \\
(-4.94)^{\star \star \star}\end{array}$ & $\begin{array}{l}-0.0744 \\
(-7.35)^{\star \star \star}\end{array}$ & $\begin{array}{c}-0.1237 \\
(-10.54)^{\star \star \star}\end{array}$ & $\begin{array}{c}-0.0710 \\
(-0.76)\end{array}$ \\
\hline $\mathbf{N}$ & 168 & 168 & 168 & 168 & 336 & 336 & 336 & 336 & 336 \\
\hline Adjusted R-squared & 0.1934 & 0.1855 & 0.5696 & 0.5757 & 0.4690 & 0.4710 & 0.6889 & 0.7289 & 0.7280 \\
\hline
\end{tabular}

Table 9: Regression results (lab):

Regression of the predicted certainty equivalent on the own certainty equivalent (normalized by the expected value). Left side: Separate regressions for 3 lotteries with 50/50probabilities and 3 lotteries with ambiguous probabilities. Right side: Regressions with all 6 lotteries.

* indicates significance at the ten percent level,** indicates significance at the five percent level, *** indicates significance at the one percent level.

\begin{tabular}{|c|c|c|c|c|c|c|c|c|c|}
\hline & \multicolumn{4}{|c|}{ Predicted CE (Lab, each with 3 Lotteries) } & \multicolumn{5}{|c|}{ Predicted CE (Lab, each with all 6 Lotteries) } \\
\hline & $50 / 50$ & $50 / 50$ & ?/? & ?/? & & & & & \\
\hline Gender & & $\begin{array}{l}-0.0647 \\
(-2.50)^{\star *}\end{array}$ & & $\begin{array}{c}-0.0096 \\
(-0.31)\end{array}$ & & & & & $\begin{array}{l}-0.0371 \\
(-1.85)^{\star}\end{array}$ \\
\hline Age & & 0.0073 & & 0.0156 & & & & & $\begin{array}{l}0.0114 \\
(2.48)^{\star \star}\end{array}$ \\
\hline Semester & & $\begin{array}{l}-0.0092 \\
(-1.69)^{*}\end{array}$ & & $\begin{array}{l}-0.0124 \\
(-1.93)^{\star}\end{array}$ & & & & & $\begin{array}{l}-0.0108 \\
(-2.56)^{\star \star}\end{array}$ \\
\hline Knowledge & & $\begin{array}{l}-0.0182 \\
(-1.65)^{\star}\end{array}$ & & $\begin{array}{c}-0.0122 \\
(-0.93)\end{array}$ & & & & & $\begin{array}{l}-0.0152 \\
(-1.77)^{\star}\end{array}$ \\
\hline Ordering & & $\begin{array}{l}-0.0414 \\
(-1.80)^{\star}\end{array}$ & & $\begin{array}{c}-0.0771 \\
(-2.81)^{\star \star \star}\end{array}$ & & & & & $\begin{array}{c}-0.0592 \\
(-3.31)^{\star \star \star}\end{array}$ \\
\hline Dummy Ambiguity & & & & & & $\begin{array}{l}-0.0314 \\
(-1.73)^{\star}\end{array}$ & & $\begin{array}{c}-0.0153 \\
(-0.83)\end{array}$ & $\begin{array}{c}-0.0148 \\
(-0.80)\end{array}$ \\
\hline Own CE * Dummy Ambi & & & & & & & $\begin{array}{c}0.1729 \\
(3.96)^{\star \star \star}\end{array}$ & $\begin{array}{c}0.1640 \\
(3.65)^{\star \star \star}\end{array}$ & $\begin{array}{c}0.1612 \\
(3.59)^{\star \star \star}\end{array}$ \\
\hline Own CE & $\begin{array}{c}0.3881 \\
(12.03)^{\star \star \star}\end{array}$ & $\begin{array}{c}0.3963 \\
(12.26)^{\star \star \star}\end{array}$ & $\begin{array}{c}0.5521 \\
(18.43)^{\star \star \star}\end{array}$ & $\begin{array}{c}0.5608 \\
(18.64)^{\star \star \star}\end{array}$ & $\begin{array}{c}0.4961 \\
(22.90)^{\star \star \star}\end{array}$ & $\begin{array}{c}0.4901 \\
(22.35)^{\star \star \star}\end{array}$ & $\begin{array}{c}0.3854 \\
(10.91)^{\star \star \star}\end{array}$ & $\begin{array}{c}0.3881 \\
(10.94)^{\star \star \star}\end{array}$ & $\begin{array}{c}0.3960 \\
(11.19)^{\star \star \star}\end{array}$ \\
\hline Constant & $\begin{array}{c}-0.0559 \\
(-4.84)^{\star \star \star}\end{array}$ & $\begin{array}{c}-0.1819 \\
(-1.46) \\
\end{array}$ & $\begin{array}{c}-0.0712 \\
(-4.86)^{\star \star \star}\end{array}$ & $\begin{array}{l}-0.2930 \\
(-1.97)^{\star \star}\end{array}$ & $\begin{array}{c}-0.0660 \\
(-7.10)^{\star \star \star}\end{array}$ & $\begin{array}{c}-0.0510 \\
(-4.01)^{\star \star \star}\end{array}$ & $\begin{array}{c}-0.0631 \\
(-6.81)^{\star \star \star}\end{array}$ & $\begin{array}{c}-0.0559 \\
(-4.40)^{\star \star \star}\end{array}$ & $\begin{array}{l}-0.2293 \\
(2.35)^{\star \star}\end{array}$ \\
\hline $\begin{array}{l}\mathbf{N} \\
\text { Adiusted R-squared }\end{array}$ & $\begin{array}{c}597 \\
01942\end{array}$ & $\begin{array}{c}597 \\
0.2039\end{array}$ & $\begin{array}{c}597 \\
03623\end{array}$ & $\begin{array}{c}597 \\
03702\end{array}$ & $\begin{array}{c}1194 \\
03049\end{array}$ & $\begin{array}{c}1194 \\
03061\end{array}$ & $\begin{array}{c}1194 \\
03133\end{array}$ & $\begin{array}{c}1194 \\
03131\end{array}$ & $\begin{array}{c}1194 \\
0.3219\end{array}$ \\
\hline
\end{tabular}


As the effects of own certainty equivalent and ambiguity do not need to be simply additive we also allow for interaction in our regression. The regression model (without control variables) is given by:

$\mathrm{CE}_{\mathrm{O}}=\alpha_{1}+\alpha_{2} *$ Dummy $+\beta_{1} * \mathrm{CE}_{\mathrm{S}}+\beta_{2} * \mathrm{CE}_{\mathrm{S}} *$ Dummy or

$\mathrm{CE}_{\mathrm{O}}=\alpha_{1}+\alpha_{2} *$ Dummy $+\left(\beta_{1}+\beta_{2} *\right.$ Dummy $) * \mathrm{CE}_{\mathrm{S}}$,

with: $\mathrm{CE}_{\mathrm{O}}$ : $\mathrm{CE}$ other: Predicted certainty equivalent (normalized by the expected value),

CEs: CE self: Own certainty equivalent (normalized with by expected value),

Dummy: 1 for ambiguous predictions, 0 otherwise.

Not surprisingly in all regressions the own certainty equivalent is highly significant at the one percent level. Adding a simple dummy variable which is 1 for the ambiguous predictions and 0 otherwise reveals no effect in the questionnaire data. The effect in the lab data is relatively weak (significant at the ten percent level). The interaction term is highly significant (on the one percent level) regardless of whether the simple dummy is included in the regression or not. The coefficient of the interaction term captures the difference in prediction power of the own certainty equivalent. This prediction power is significantly higher for ambiguous lotteries. The coefficient for the dependant variable own certainty equivalent is now given by $\left(\beta_{1}+\beta_{2} *\right.$ Dummy), so in lotteries with fixed probabilities it is just $\beta_{1}$ but for ambiguous lotteries the coefficient is $\beta_{1}+\beta_{2}$. Thus the predicted certainty equivalent is higher the higher the own certainty equivalent is and with ambiguity this relationship is even stronger.

The constant term in the regression is given by $\alpha_{1}+\alpha_{2}^{*}$ Dummy, it is simply $\alpha_{1}$ for the 50/50-probabilities and $\alpha_{1}+\alpha_{2}$ for the ambiguous cases. $\alpha_{2}$ is significant for the questionnaire date (compare columns 9 and 10, Table 8), the constant term is higher with ambiguity. For the lab data $\alpha_{2}$ is not significant (compare columns 9 and 10, Table 9).

The previous analysis very clearly shows that the false consensus effect is present also in financial decisions. Even if the group seems to be able to give a good prediction the predictions of a single individual is egocentrically biased. Indeed we found that people are partly aware that they are more or less risk seeking than the average individual and adjust their own certainty equivalent in the right direction, so the prediction is not equal to the own certainty equivalent. But the own preference is not adjusted highly enough. In addition, we found that the bias is higher in situations with higher uncertainty. Having to give a prediction in the case of an ambiguous lottery people's egocentric bias is stronger. 


\section{Interval analysis}

In this subsection we report the results from the interval predictions. In the lab experiment participants were asked to state a lower bound that they think is not fallen short by more than $5 \%$ of the participants and also an upper bound which is not exceeded by more than $5 \%$. We are interested if people are aware of the of variety of others' preferences. Are they able to imagine that others might have absolutely different preferences compared to their own. It may be that they are wrong in predicting the average but aware of the range of preferences. In contrast to this it may also be the case that they are right in predicting the average but fail to imagine individual differences. Figure 5 shows a histogram of stated certainty equivalents for the 50/50-lottery $(1000,0)$. The vertical lines include the 90 percent interval, 50 is the true lower bound and 750 the true upper bound.

Figure 5: Histogram of stated certainty equivalents for the $50 / 50$-lottery $(1000,0)$, The vertical lines indicate the 90 percent interval (50-750).

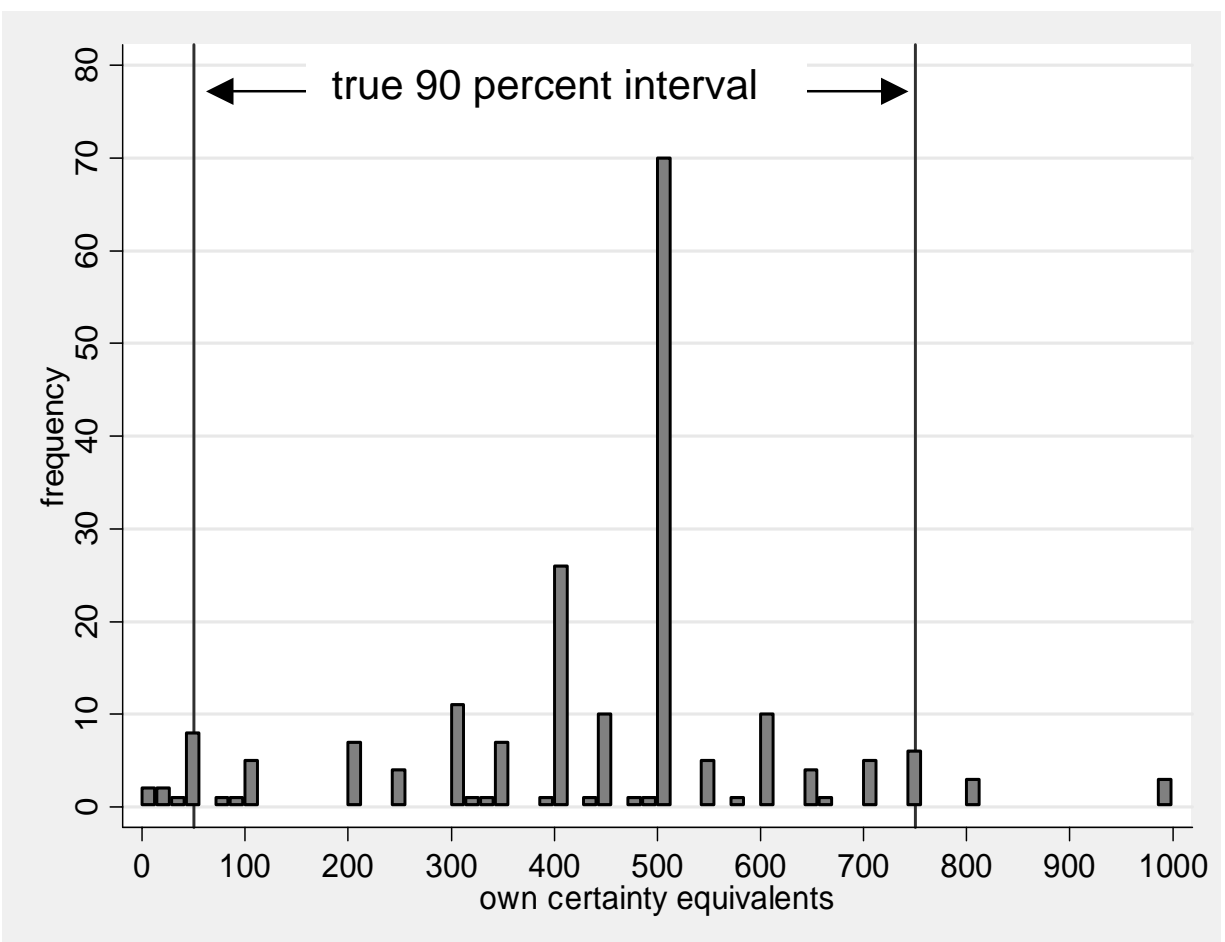

Figure 6 shows the predicted intervals by the participants. The average predicted lower bound for the 50/50-lottery $(1000,0)$ is 239.75 (median 200), only 29 of 199 predicted the bound to be equal or below 50. The average predicted upper bound is 646.11 (median 600). In this case 74 participants stated an upper bound equal to or above 750 . Only 11 subjects were able to 
state a lower bound low enough and at the same time an upper bound high enough, i.e. to give an interval that contains the true 90 percent interval.

The intervals are ordered by the size of the own certainty equivalents (x-axis from low to high).

Figure 6: Predicted 90 percent intervals for the 50/50-lottery (1000,0),

The intervals are ordered by the size of the own certainty equivalents ( $x$-axis from low to high). The true 90 percent interval (50-750) is indicated by horizontal lines.

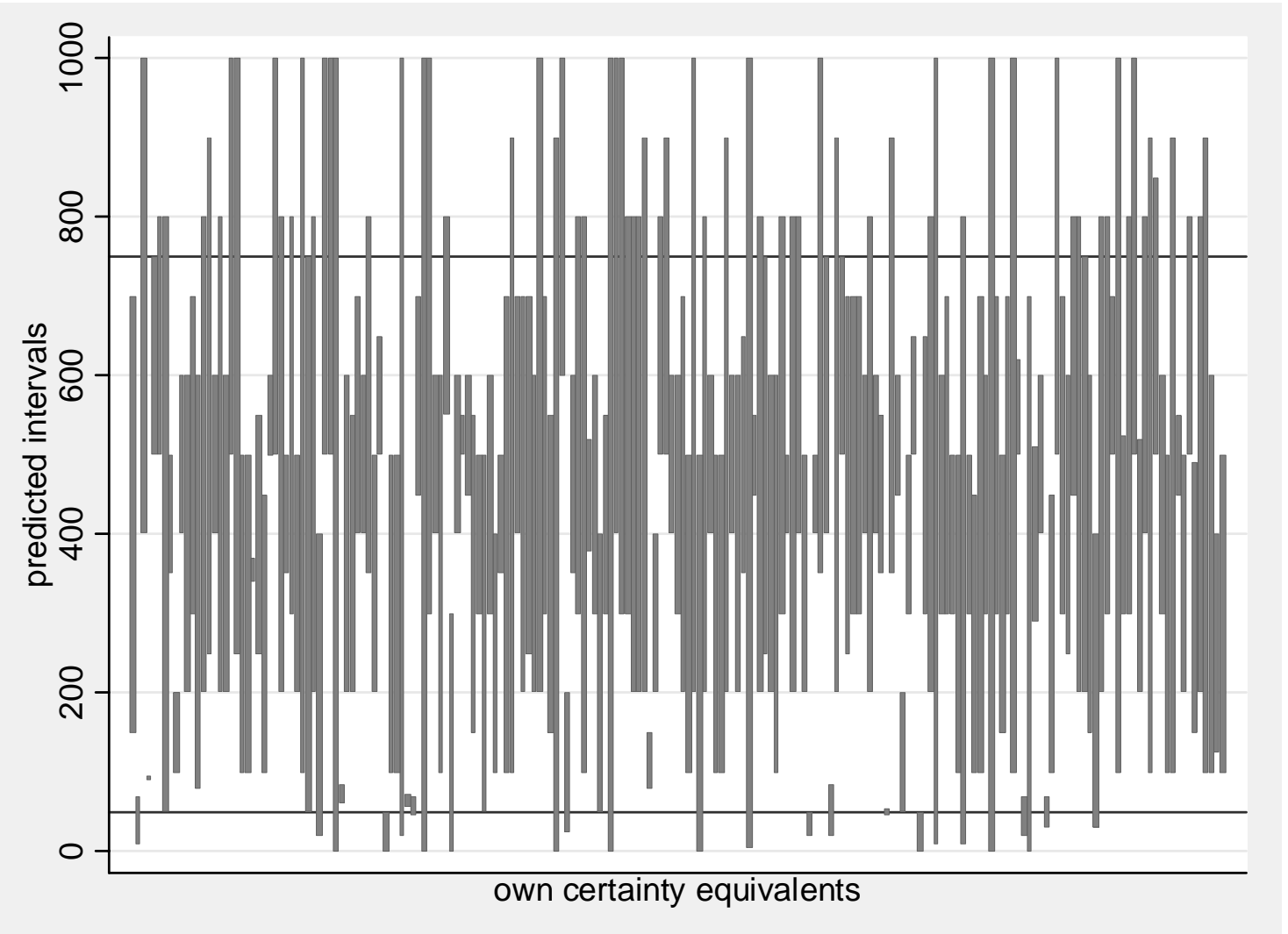

Table 9: True and predicted lower and upper bounds,

the true bounds are given in column 2, column 3 states the mean and median predictions. Column 4 gives the number of correct predictions (lower bound correct, i.e. low enough, upper bound correct, i.e. high enough, both bounds correct)

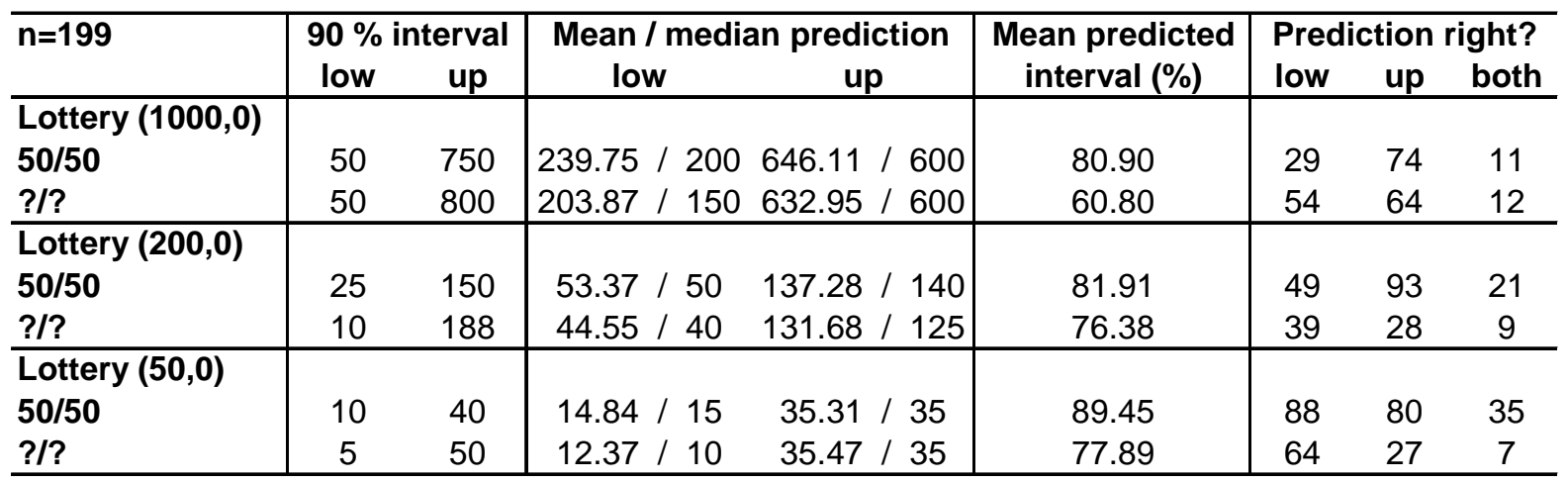


Appendix G shows histograms of the other 5 lotteries. Table 9 summarizes the results for all six lotteries. Column 2 shows the true 90 percent interval, column 3 the predicted lower and upper bounds. Column 4 displays the proportion of certainty equivalents which would be included between the mean lower and the mean upper bound. As an example take the 50/50lottery $(1000,0)$ : the true 90 percent interval is 50 to 750 . But the mean predicted interval 239.75 to 646.11 contains only 80.90 percent of the certainty equivalents of all participants. Column 5 shows the number of subjects who were able to give both: a lower bound low enough and an upper bound high enough. For the 50/50-lottery $(1000,0) 29$ participants gave a lower bound low enough, 74 gave an upper bound high enough and only 11 of them gave both at the same time. The true 90 percent intervals are larger for the ambiguous lotteries, for the $(1000,0)$-lottery only the upper bound is higher, for the other two lotteries the upper bounds are higher and simultaneously the lower bounds are lower for the ambiguous lottery. This is in line with the descriptive statistics (Table 2) as the standard deviation is higher for stated own certainty equivalents as well as for predicted certainty equivalents in case of ambiguity.

The results obviously show that the vast majority is not able to predict the variation in others' certainty equivalents correctly. Others are predicted to be too consistent in their decisions, the 90 percent intervals are too tight. The effect is stronger for ambiguous predictions. The predicted intervals contain about 80 to 90 percent of the certainty equivalents for the 50/50lotteries, but only about 60 to 80 percent for the ambiguous lotteries.

Table 10 states regression results. It is similar to Table 7, but this time the dependent variables are predicted lower and upper bounds instead of predicted average certainty equivalents. Again, the own certainty equivalent is a highly significant explanatory variable. The higher the own certainty equivalent the higher the predicted lower bound and the same with the upper bound. Again the effect seems to be greater in situations with ambiguity as the regression coefficient of the own certainty equivalent as well as the adjusted R-squared are higher in ambiguous situations. Even though we find a positive regression coefficient of the own certainty equivalent for the lower and for the upper predicted bound it is noteworthy that we cannot find a correlation between total size of the interval and size of the own certainty equivalent. 
Table 10: Regression results (lab): regression of the predicted lower and upper bounds on the own certainty equivalent and control variables. * indicates significance at the ten percent level, $* *$ indicates significance at the five percent level, $* * *$ indicates significance at the one percent level.

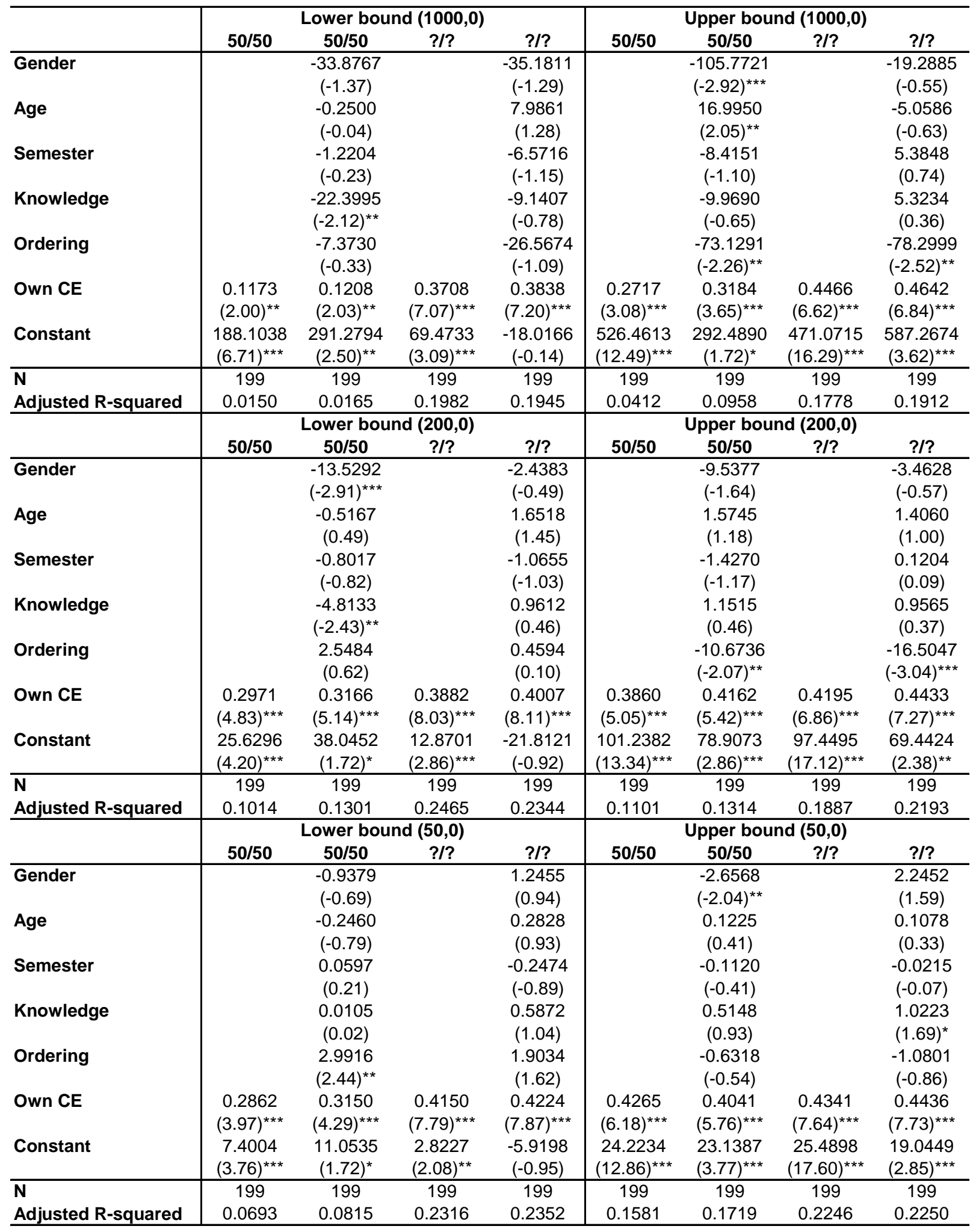


To test whether the influence of ambiguity is significant for predicting the interval we use combined regressions again with data from all six lotteries. The regression models (equivalent to Table 9) are given by:

$L B_{O}=\alpha_{1}+\alpha_{2} *$ Dummy $+\left(\beta_{1}+\beta_{2} *\right.$ Dummy $) * C E_{S}$ (left part of Table 11) and

$U B_{O}=\alpha_{1}+\alpha_{2} *$ Dummy $+\left(\beta_{1}+\beta_{2} *\right.$ Dummy $) * C E_{S}$ (right part of Table11),

with: LB $_{\mathrm{O}}$ : LB other: Predicted lower bound of others' certainty equivalents (normalized by the expected value),

$\mathrm{UB}_{\mathrm{O}}$ : UB other: Predicted upper bound of others' certainty equivalents (normalized by the expected value),

Dummy: 1 for ambiguous predictions, 0 otherwise.

Table 11: Regression results (lab): regression with all 6 lotteries of the predicted lower (left side) and upper bounds (right side) on the own certainty equivalent and control variables. $*$ indicates significance at the ten percent level,** indicates significance at the five percent level, $* * *$ indicates significance at the one percent level.

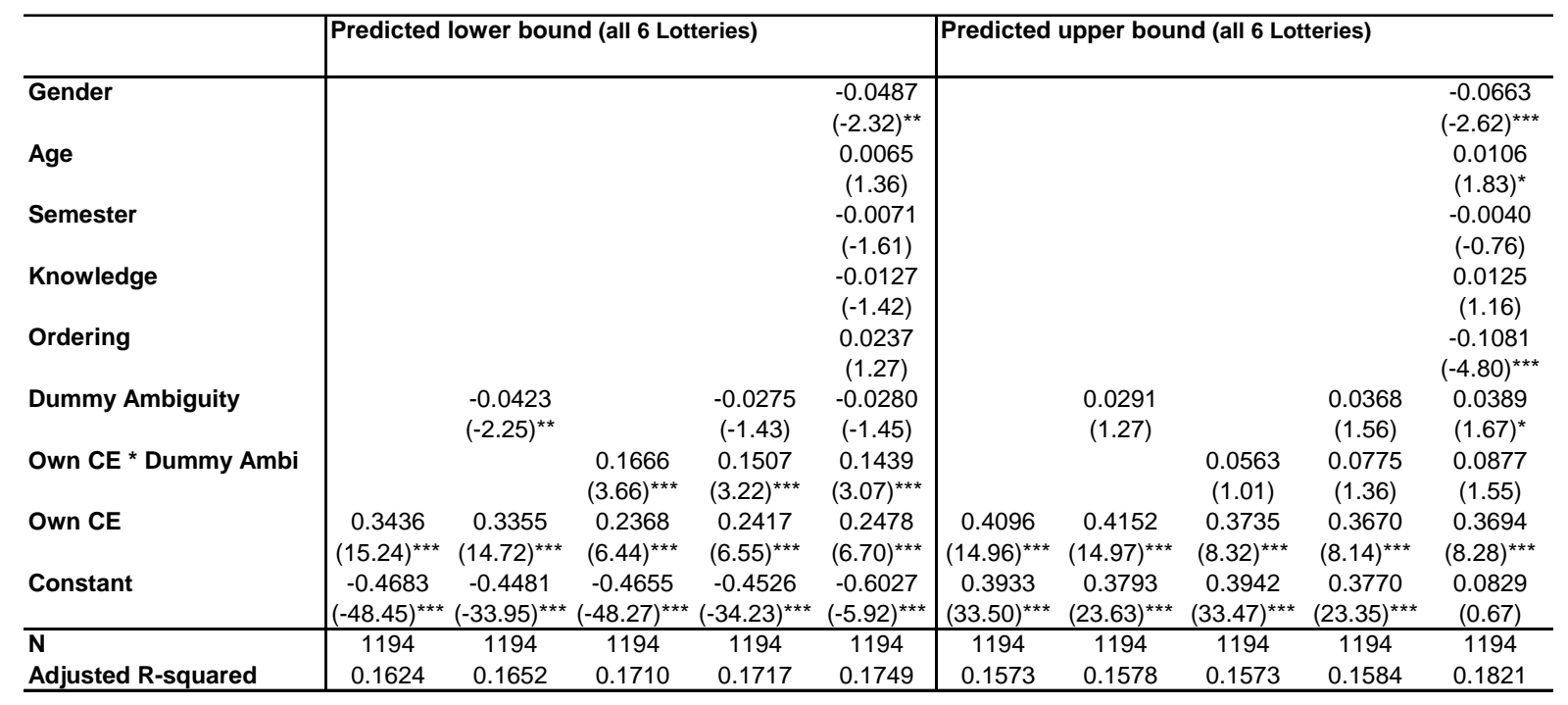

As expected the influence of the own certainty equivalent is highly significant for the predicted lower as well as for the predicted upper bound. Adding a simple dummy variable which is 1 for ambiguous predictions and 0 otherwise yields a significant effect only for the predicted lower bound. The model with interaction term shows that the influence of the own certainty equivalent is higher for the ambiguous lottery, i.e. $\beta_{2}$ is significant. The effect is robust to the inclusion of control variables. Of the control variables only gender yields a significant effect in the sense that men predict the lower bound to be smaller. For the upper bound a simple ambiguity dummy and an interaction term have no significant explanatory 
power. Adding control variables leads to a significant effect (ten percent level) of the simple dummy, i.e. $\alpha_{2}$ is significant. The t-statistic for the interaction term is 1.55 , this corresponds to a significance level of 13 percent thus the tendency is in line with the effect for the lower bound. Again men predict the upper bound to be smaller than women. The older a person the higher the upper bound and the predicted upper bound is lower if participants first gave a prediction of other certainty equivalent as well as an interval prediction before stating their own certainty equivalent.

The results from the interval analysis can be summarized as follows. People are not able to estimate the variance of other peoples' risk preferences correctly. The predicted 90 percent intervals are much too tight (Table 9). The relatively more risk averse people give smaller lower as well as smaller upper bounds and the relatively more risk seeking people give higher lower and upper bounds. There is at least the tendency that the influence of the own certainty equivalent is even stronger in ambiguous situations.

\section{Conclusion}

In two studies we found strong evidence for a false consensus effect in financial lottery questions. In contrast to Hsee and Weber (1997) in their first two treatments or Faro and Rottenstreich (2006) we do not find an effect on the aggregated level. The average predictions of others certainty equivalents in our studies are in general not significantly different from the average certainty equivalent. Our results are in line with the third treatment of Hsee and Weber as they do not find an average effect when the other person is specified as the person sitting next to them.

However, we find effects on the individual level that have not been analyzed by other studies in the financial context. Our results show that relatively more risk averse people adjust their prediction in the right direction. They predict the average certainty equivalent to be higher than their own certainty equivalent, but this prediction is still too risk averse, i.e. the predicted certainty equivalent is too low. The same results are found for the relatively more risk seeking subjects. They predict that others are relatively more risk averse compared to themselves and they are right. But again, their adjustment is not strong enough, the prediction is still too risk seeking.

Moreover, we extend the scope of Gilovich (1990) to financial decisions, i.e. we do not only analyze 50/50-lotteries but also lotteries with ambiguous probabilities. As expected, we find 
the false consensus effect to be even stronger for these ambiguous lotteries. The explanatory power of the own preference is higher for lotteries with ambiguous probabilities.

In the lab experiment we also asked participants to state a 90 percent interval. Only very few students were able to state a correct interval (Table 7). The spread in other people's preferences is highly underestimated. Again we find a significant influence of the own preference. The higher the own certainty equivalent the higher the predicted lower and upper bounds. For ambiguous lotteries the influence of the own certainty equivalent tends to be stronger.

In practice assessing the real preferences of people whom one does not know or assessing the average individual is quite a common task. Think of a fund manager investing money for a group of investors or of a medical firm that develops a new medicine and has to decide on the trade off between efficiency and adverse effects. If individuals have difficulties to abstract from their own risk preference this leads to a biased prediction of others' preferences and choices on behalf of others may be sub optimal. Moreover, an individual is not able to access the spread in others' preferences correctly. For a financial advisor, for example, this underestimation of variety of opinions could lead to a too standardized advice concept.

The more uncertainty is involved in a situation the stronger the bias is. As most financial decisions in the real world imply a high degree of uncertainty (risky outcomes, risky probabilities, risky environment, e.g. legal regulation etc.) it is especially important to have detailed information about potential clients’ risk preferences. 


\section{References}

Camerer, C. F., R. M. Hogarth (1999): The Effects of Financial Incentives in Experiments: A Review and Capital-Labor-Production Framework, Journal of Risk and Uncertainty, 19, 7-42.

Dohmen, T. J., A. Falk, D. Huffman, J. Schupp, U. Sunde, G. G. Wagner (2005): Individual Risk Attitudes: New Evidence from a Large, Representative, Experimentally-Validated Survey, CERP-Discussion Paper No. 5517, February 2006.

Ellsberg, D. (1961): Risk, Ambiguity, and the Savage Axioms, Quarterly Journal of Economics 75: 643-669.

Engelmann, D., M. Stroebel (2004): The False Consensus Effect: Deconstruction and Reconstruction of an Anomaly, Working Paper (July 29, 2004).

Epley, N., B. Keysar, L. Van Boven, T. Gilovich (2004): Perspective taking as egocentric adjustment, Journal of Personality and Social Psychology, 87, 327-339.

Faro, D., Y. Rottenstreich (2006): Affect, Empathy, and Regressive Mispredictions of Others' Preferences Under Risk, Management Science, 52, 529-541.

Gilovich, T. (1990): Differential Construal and the False Consensus Effect, Journal of Personality and Social Psychology, 59, 623-634.

Gilovich, T., V.H. Medvec, K. Savitsky (2000): The spotlight effect in social judgment: An egocentric bias in estimates of the salience of one's own actions and appearance, Journal of Personality and Social Psychology, 78, 211-222.

Gilovich, T., K. Savitsky, V.H. Medvec (1998): The illusion of transparency: Biased assessments of others' ability to read our emotional states, Journal of Personality and Social Psychology, 75, 332-346.

Johnson, P. (2004): Academy Awards, Sharon Stone and Market Efficiency, http://www.capatcolumbia.com/Academy\%20Awards/academy\%20awards.htm (28.05.2007).

Tversky, A., D. Kahneman (1986): Rational choice and the framing of decisions, Journal of Business, 59, 251-278.

Hsee, C. K., E. U. Weber (1997): A fundamental prediction error. Self-other differences in risk preferences, Journal of Experimental Psychology, 126, 45-53.

Marks, G., N. Miller (1987): Ten Years of Research on the False Consensus Effect: An Empirical and Theoretical Review, Psychological Bulletin, 102, 72-90.

Mullen, B., L. Atkins, D. S. Champion, C. Edwards, D. Hardy, E. Story, M. Vanderklok (1985): The False Consensus Effect: A Meta-analysis of 115 Hypothesis Tests, Journal of Experimental Social Psychology, 21; 262-283.

Nickerson, R. S. (1999): How we know|and sometimes misjudge|what others know: Imputing one's own knowledge to others, Psychological Bulletin, 125, 737-759. 
Ross, L., D. Greene, P. House (1977): The "False Consensus Effect": An Egocentric Bias in Social Perception and Attribution Processes, Journal of Experimental Social Psychology, 13, 279-301.

Roszkowski, M. J., J. Grable (2005): Estimating Risk Tolerance: The Degree of Accuracy and the Paramorphic Representations of the Estimate, in: Financial Counseling and Planning, 16, 29-47.

Tversky, A., D. Kahneman (1974): Judgment under uncertainty: Heuristics and biases, Science, 185, 1124-1130. 


\section{Appendix A: Questionnaire}

Liebe Studierende,

bitte lesen Sie diese kurze Anleitung sorgfältig durch, bevor Sie mit der Beantwortung der Fragen beginnen.

Im Folgenden sind verschiedene Lotterien dargestellt, zu denen wir Sie jeweils um eine Indifferenzaussage bitten werden.

Indifferenz zwischen zwei Alternativen bedeutet, dass es Ihnen egal ist, welche der zwei Alternativen Sie bekommen. Wenn Sie also beispielsweise vor zwei Eisbechern sitzen, einer mit Erdbeereis, der andere mit Vanilleeis, und es Ihnen egal ist, welchen der beiden Sie bekommen, dann sind Sie indifferent zwischen den Alternativen Erdbeerbecher und Vanillebecher.

Indifferenz zwischen einer Lotterie und einer sicheren Zahlung bedeutet somit, dass es Ihnen egal ist, ob Sie an der Lotterie teilnehmen oder die sichere Zahlung erhalten.

Als kleines Dankeschön werden aus den beantworteten Fragebögen 5 Teilnehmer ausgelost, die jeweils $10 €$ erhalten.

Wenn Sie an der Verlosung teilnehmen möchten, tragen Sie bitte noch hier Ihre Matrikel-Nummer ein. Matrikel-Nummer:

Dieses Deckblatt wird vor der Auswertung abgetrennt, Ihre Daten werden selbstverständlich anonym ausgewertet.

Und los geht's... 
1. Die folgende Lotterie zahlt entweder $100 €$ oder $0 €$ aus. Stellen Sie sich vor, dass in einer Urne genau 100 Kugeln sind, davon sind 50 Kugeln gelb und 50 Kugeln weiß. Wird eine gelbe Kugel gezogen, so gewinnen Sie $100 €$, wird eine weiße Kugel gezogen, so gewinnen Sie nichts.

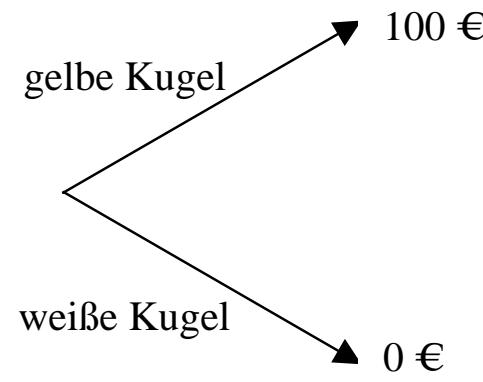

Bitte geben Sie an, bei welcher Zahlung, die Sie sicher erhalten würden, Sie indifferent wären zwischen dieser sicheren Zahlung und der obigen Lotterie?

Was glauben Sie, für welche Zahlung die Teilnehmer dieser Studie (also Studenten, die die Übung Bankbetriebslehre besuchen) im Durchschnitt indifferent wären zwischen dieser sicheren Zahlung und der obigen Lotterie? $€$

2. Die folgende Lotterie zahlt entweder $100 €$ oder $0 €$ aus. Stellen Sie sich vor, dass in einer Urne genau 100 Kugeln, gelbe und weiße, sind. Der jeweilige Anteil ist dabei allerdings unbekannt. Wird eine gelbe Kugel gezogen, so gewinnen Sie $100 €$, wird eine weiße Kugel gezogen, so gewinnen Sie nichts.

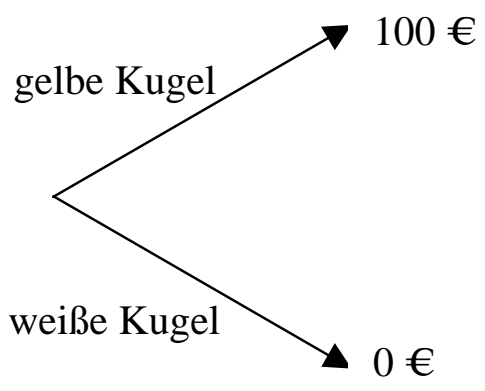

Bitte geben Sie an, bei welcher Zahlung, die Sie sicher erhalten würden, Sie indifferent wären zwischen dieser sicheren Zahlung und der obigen Lotterie? $€$

Was glauben Sie, für welche Zahlung die Teilnehmer dieser Studie im Durchschnitt indifferent wären zwischen dieser sicheren Zahlung und der obigen Lotterie? $€$ 
3. Die folgende Lotterie zahlt entweder $200 €$ oder $50 €$ aus. Stellen Sie sich vor, dass in einer Urne genau 100 Kugeln sind, davon sind 50 Kugeln gelb und 50 Kugeln weiß. Wird eine gelbe Kugel gezogen, so gewinnen Sie $200 €$, wird eine weiße Kugel gezogen, so gewinnen Sie $50 €$.

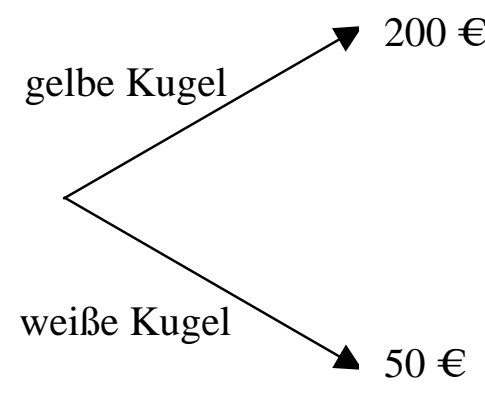

Bitte geben Sie an, bei welcher Zahlung, die Sie sicher erhalten würden, Sie indifferent wären zwischen dieser sicheren Zahlung und der obigen Lotterie? $€$

Was glauben Sie, für welche Zahlung die Teilnehmer dieser Studie im Durchschnitt indifferent wären zwischen dieser sicheren Zahlung und der obigen Lotterie? $€$

4. Die folgende Lotterie zahlt entweder $200 €$ oder $50 €$ aus. Stellen Sie sich vor, dass in einer Urne genau 100 Kugeln, gelbe und weiße, sind. Der jeweilige Anteil ist dabei allerdings unbekannt. Wird eine gelbe Kugel gezogen, so gewinnen Sie $200 €$, wird eine weiße Kugel gezogen, so gewinnen Sie $50 €$.

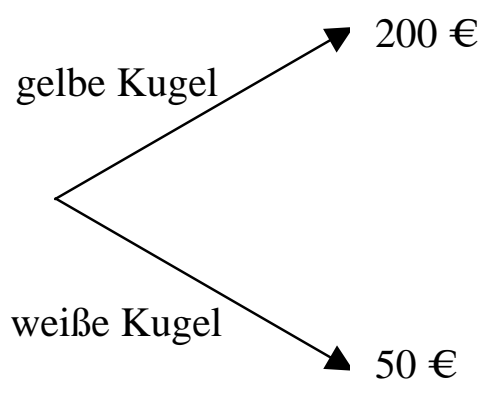

Bitte geben Sie an, bei welcher Zahlung, die Sie sicher erhalten würden, Sie indifferent wären zwischen dieser sicheren Zahlung und der obigen Lotterie?

Was glauben Sie, für welche Zahlung die Teilnehmer dieser Studie im Durchschnitt indifferent wären zwischen dieser sicheren Zahlung und der obigen Lotterie? $€$ 
Zum Schluss benötigen wir noch einige Angaben zu Ihrer Person:

Ihr Geschlecht:

weiblich $\mathrm{O}$

männlich $\quad \mathrm{O}$

Ihr Alter in Jahren: Jahre

Ihr Studiengang:

Vielen Dank für Ihre Teilnahme! 


\section{Appendix B: Ordering effects}

Table B.1: Differences in own certainty equivalents subject to the ordering of questions (self before other: predictions follow statements of own certainty equivalents, other before self: statements of own certainty equivalents follow predictions).

self before other:

\begin{tabular}{l|rrrrrr} 
lottery & $\mathbf{( 1 0 0 0 , 0 )}$ & $\mathbf{( 2 0 0 , 0 )}$ & $\mathbf{( 5 0 , 0 )}$ & $\mathbf{( 1 0 0 0 , 0 )}$ & $\mathbf{( 2 0 0 , 0 )}$ & $\mathbf{( 5 0 , 0 )}$ \\
prob. & $\mathbf{5 0 / 5 0}$ & $\mathbf{5 0 / 5 0}$ & $\mathbf{5 0 / 5 0}$ & $\mathbf{?} \mathbf{?}$ & $\mathbf{?}, \mathbf{?}$ & $\mathbf{?}$ ? \\
\hline ce self & $\mathbf{s 1 a}$ & $\mathbf{s 1 b}$ & $\mathbf{s 1 c}$ & $\mathbf{s 2 a}$ & $\mathbf{s 2 b}$ & $\mathbf{s 2 c}$ \\
\hline mean & 419,83 & 91,38 & 27,52 & 336,17 & 79,77 & 23,17 \\
median & 500,00 & 100,00 & 25,00 & 300,00 & 75,00 & 22,50 \\
sd & 184,50 & 30,50 & 9,23 & 250,69 & 48,61 & 12,19 \\
min & 0,00 & 0,00 & 5,00 & 0,00 & 2,00 & 0,50 \\
max & 1000,00 & 200,00 & 50,00 & 1000,00 & 200,00 & 50,00
\end{tabular}

other before self:

\begin{tabular}{l|rrrrrr} 
ce self & s1a & s1b & s1c & s2a & s2b & s2c \\
\hline mean & 457,95 & 95,08 & 24,67 & 385,10 & 83,19 & 22,85 \\
median & 500,00 & 100,00 & 25,00 & 400,00 & 85,00 & 25,00 \\
sd & 187,48 & 36,59 & 7,35 & 207,69 & 41,59 & 9,92 \\
min & 0,00 & 5,00 & 5,00 & 3,00 & 1,00 & 0,10 \\
max & 1000,00 & 200,00 & 50,00 & 1000,00 & 200,00 & 50,00 \\
Wilcoxon & & & & & & \\
& not sig & not sig & $\mathrm{p}<0,10$ & $\mathrm{p}<0,05$ & not sig & not sig
\end{tabular}

Table B.2: Differences in predicted certainty equivalents subject to the ordering of questions (self before other: predictions follow statements of own certainty equivalents, other before self: statements of own certainty equivalents follow predictions).

self before other:

\begin{tabular}{l|rrrrrr} 
lottery & $\mathbf{( 1 0 0 0 , 0 )}$ & $\mathbf{( 2 0 0 , 0 )}$ & $\mathbf{( 5 0 , 0 )}$ & $\mathbf{( 1 0 0 0 , 0 )}$ & $\mathbf{( 2 0 0 , 0 )}$ & $\mathbf{( 5 0 , 0 )}$ \\
prob. & $\mathbf{5 0 / 5 0}$ & $\mathbf{5 0 / 5 0}$ & $\mathbf{5 0 / 5 0}$ & $\mathbf{?} / \mathbf{?}$ & $\mathbf{?} / \mathbf{?}$ & $\mathbf{?} / ?$ \\
\hline ce other & $\mathbf{a 1 1 a 1}$ & $\mathbf{a 1 1 b 1}$ & $\mathbf{a 1 1 c 1}$ & $\mathbf{a 1 2 a 1}$ & $\mathbf{a 1 2 b 1}$ & $\mathbf{a 1 2 c 1}$ \\
\hline mean & 442,42 & 94,39 & 25,28 & 405,67 & 85,79 & 22,49 \\
median & 500,00 & 100,00 & 25,00 & 400,00 & 80,00 & 20,00 \\
sd & 161,13 & 31,67 & 8,15 & 241,17 & 43,85 & 10,21 \\
$\min$ & 50,00 & 20,00 & 10,00 & 10,00 & 10,00 & 5,00 \\
$\max$ & 1000,00 & 200,00 & 50,00 & 1000,00 & 200,00 & 50,00
\end{tabular}

other before self:

\begin{tabular}{l|rrrrrr} 
ce other & a11a1 & a11b1 & a11c1 & a12a1 & a12b1 & a12c1 \\
\hline mean & 408,79 & 92,04 & 24,56 & 377,18 & 77,71 & 22,21 \\
median & 500,00 & 100,00 & 25,00 & 400,00 & 75,00 & 20,00 \\
sd & 166,90 & 24,92 & 7,19 & 214,32 & 35,52 & 9,46 \\
min & 20,00 & 10,00 & 3,00 & 10,00 & 2,00 & 1,00 \\
max & 750,00 & 150,00 & 50,00 & 1000,00 & 200,00 & 50,00 \\
\multicolumn{1}{l}{ Wilcoxon } & not sig & not sig & not sig & not sig & not sig & not sig
\end{tabular}




\section{Appendix C: Median splits}

Table C.1: Splitting results,

mean and median certainty equivalents within different groups (Questionnaire). In the first Table median observations are added to the relatively more risk averse subgroup, in the second Table median observations are added to the relatively more risk seeking subgroup.

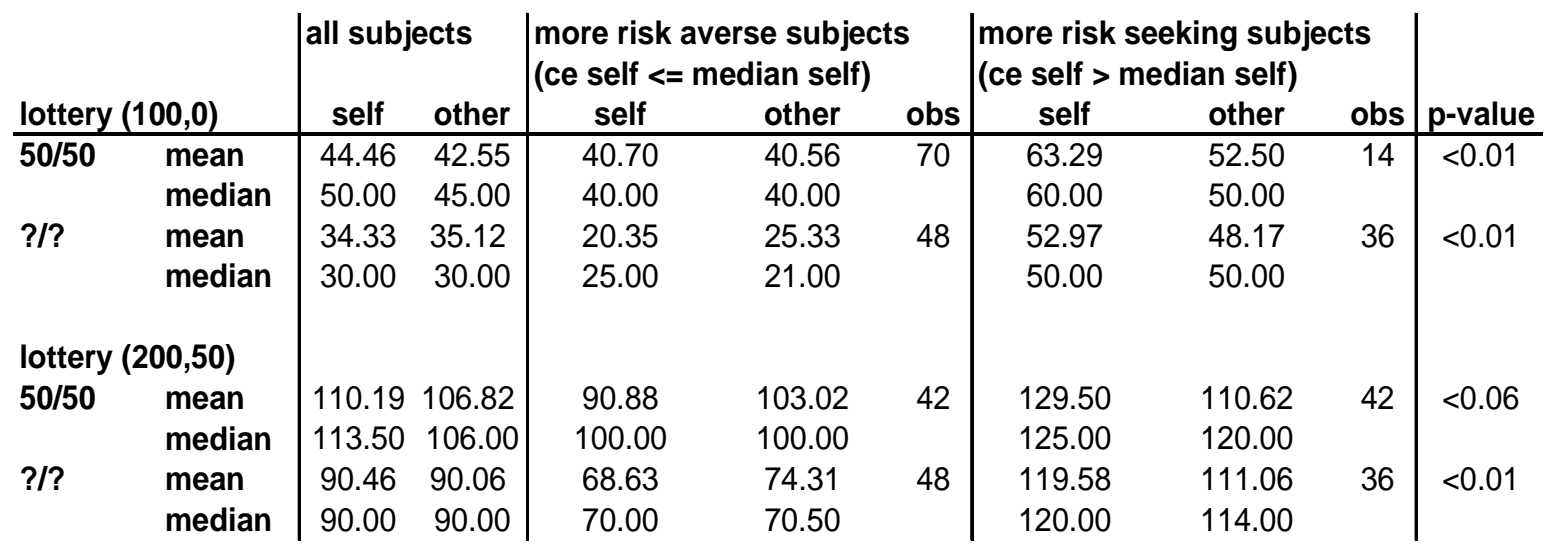

\begin{tabular}{|c|c|c|c|c|c|c|c|c|c|c|}
\hline \multirow{2}{*}{\multicolumn{2}{|c|}{ lottery $(100,0)$}} & \multicolumn{2}{|c|}{ all subjects } & \multicolumn{3}{|c|}{\begin{tabular}{|l} 
more risk averse subjects \\
(ce self < median self)
\end{tabular}} & \multicolumn{3}{|c|}{\begin{tabular}{|l} 
more risk seeking subjects \\
(ce self $>=$ median self)
\end{tabular}} & \multirow[b]{2}{*}{ p-value } \\
\hline & & self & other & self & other & obs & self & other & obs & \\
\hline \multirow[t]{2}{*}{$50 / 50$} & mean & 44.46 & 42.55 & 33.73 & 37.33 & 40 & 54.23 & 47.30 & 44 & $<0.01$ \\
\hline & median & 50.00 & 45.00 & 35.00 & 40.00 & & 50.00 & 50.00 & & \\
\hline \multirow[t]{2}{*}{ ?/? } & mean & 34.33 & 35.12 & 13.46 & 21.75 & 28 & 44.77 & 41.80 & 56 & $<0.01$ \\
\hline & median & 30.00 & 30.00 & 10.00 & 15.00 & & 40.00 & 40.00 & & \\
\hline \multicolumn{11}{|c|}{ lottery $(200,50)$} \\
\hline \multirow[t]{2}{*}{$50 / 50$} & mean & 110.19 & 106.82 & 90.88 & 103.02 & 42 & 129.50 & 110.62 & 42 & $<0.06$ \\
\hline & median & 113.50 & 106.00 & 100.00 & 100.00 & & 125.00 & 120.00 & & \\
\hline \multirow[t]{2}{*}{ ?/? } & mean & 90.46 & 90.06 & 64.35 & 70.43 & 40 & 114.20 & 107.91 & 44 & $<0.01$ \\
\hline & median & 90.00 & 90.00 & 65.00 & 70.00 & & 100.00 & 105.00 & & \\
\hline
\end{tabular}


Table C.2: Splitting results, mean and median certainty equivalents within different groups (lab). In the first Table median observations are added to the relatively more risk averse subgroup, in the second Table median observations are added to the relatively more risk seeking subgroup.

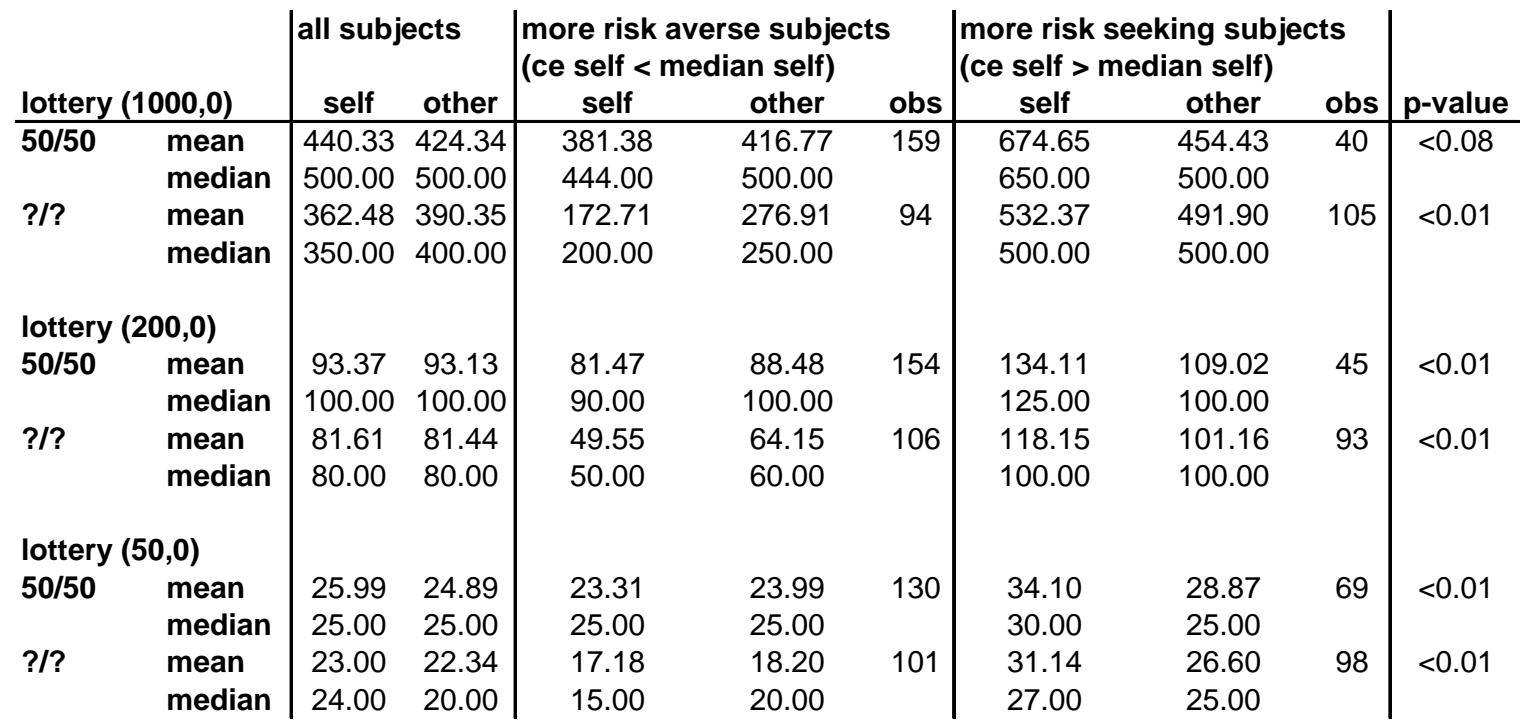

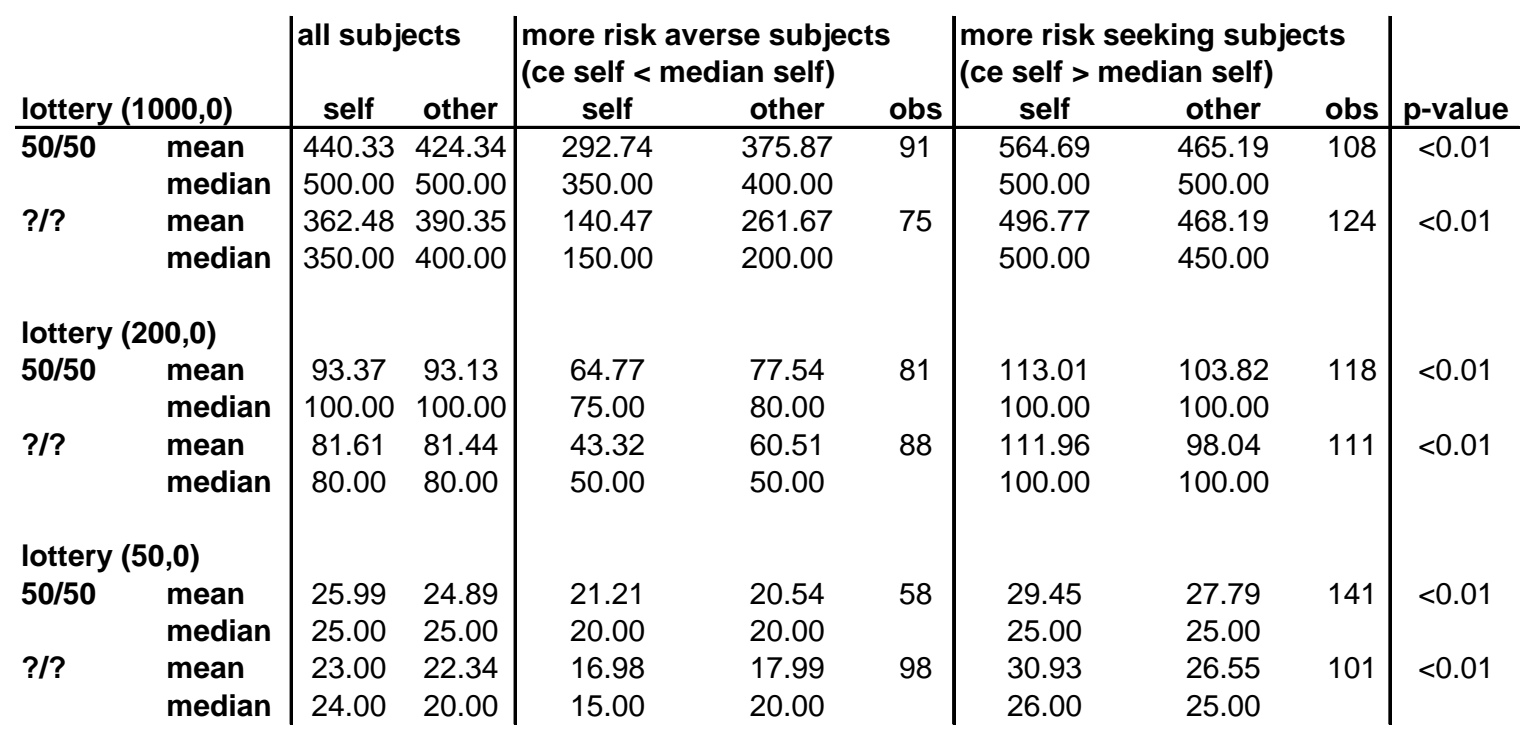


Appendix D: Lottery plots

Figure D.1: Plot of the (200,50)-lottery and regression lines for 50/50- and ?/?probabilities.

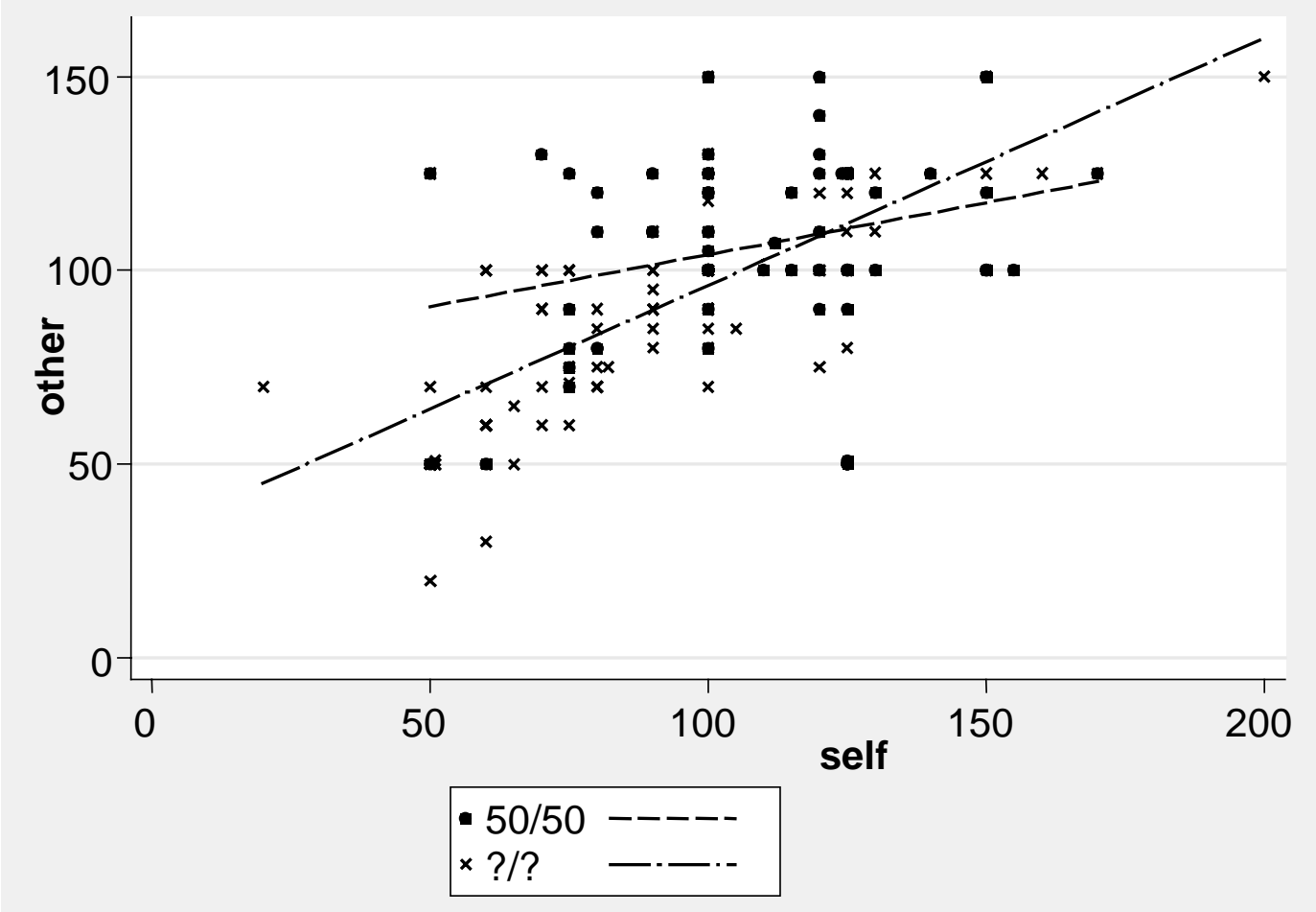

Figure D.2: Plot of the $(1000,0)$-lottery and regression lines for $50 / 50$ - and ?/?probabilities.

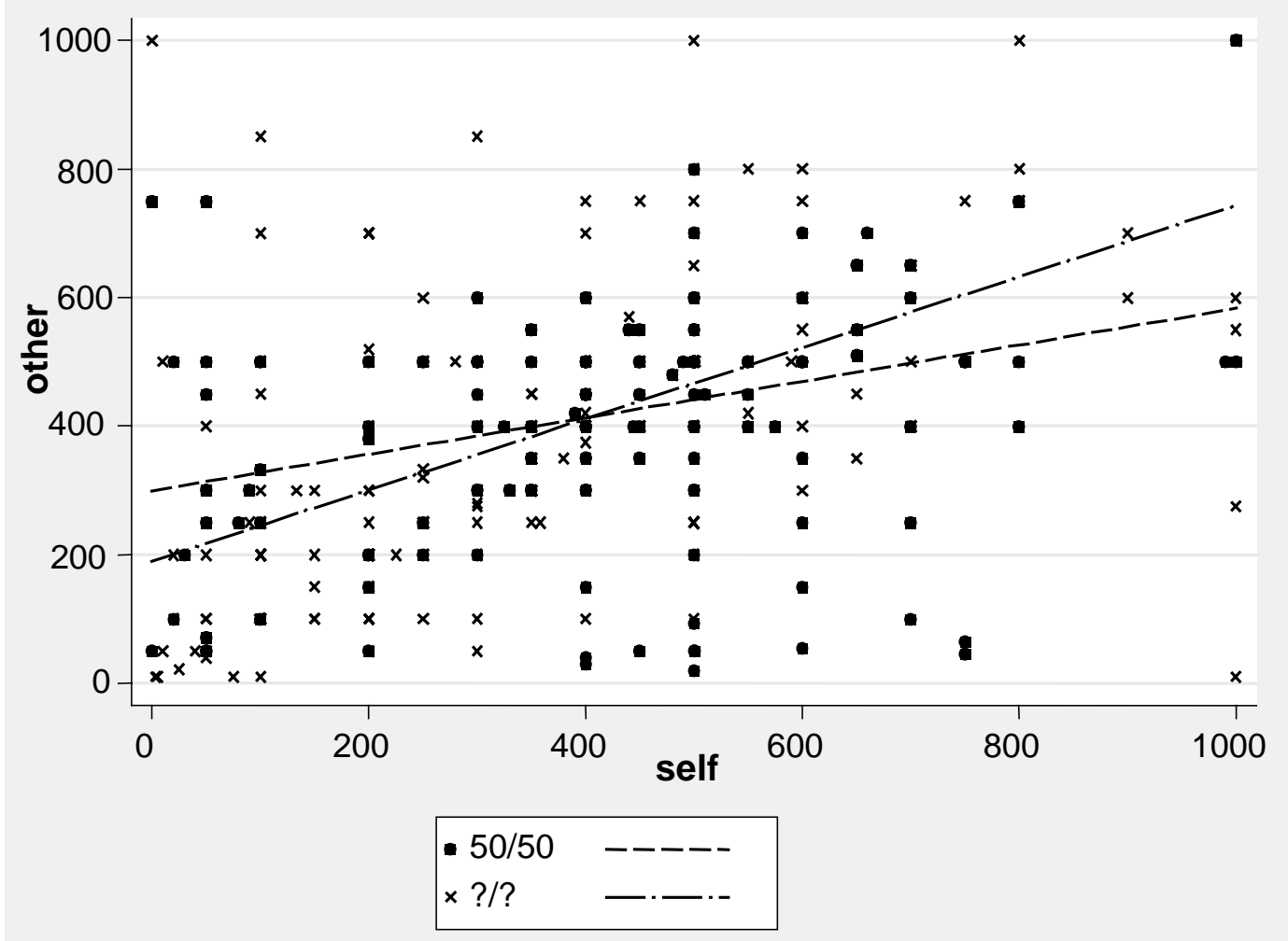


Figure D.3: Plot of the $(\mathbf{2 0 0 , 0})$-lottery and regression lines for $50 / 50-$ and ?/?probabilities.

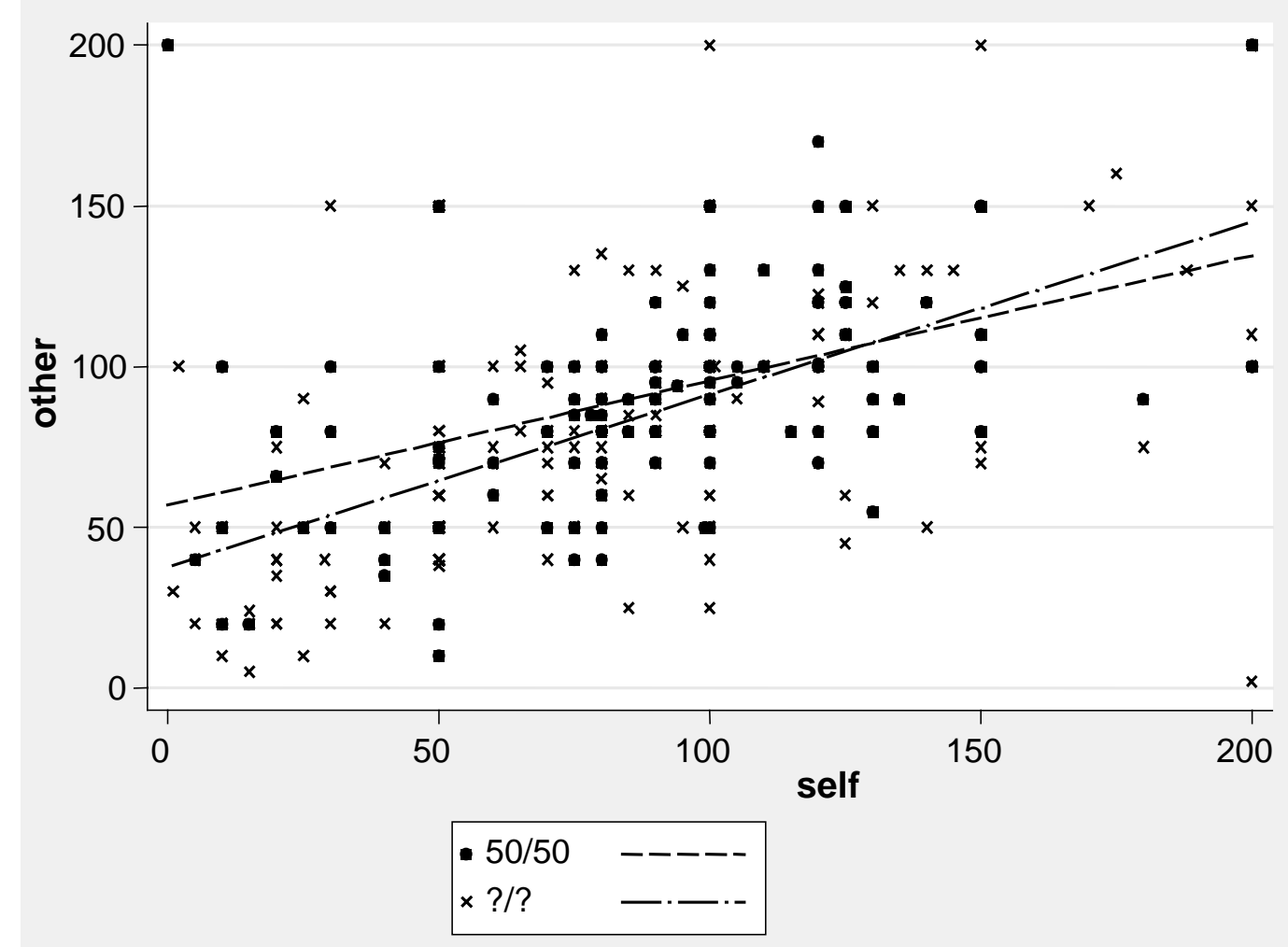

Figure D.4: Plot of the (50,0)-lottery and regression lines for 50/50- and ?/?probabilities.

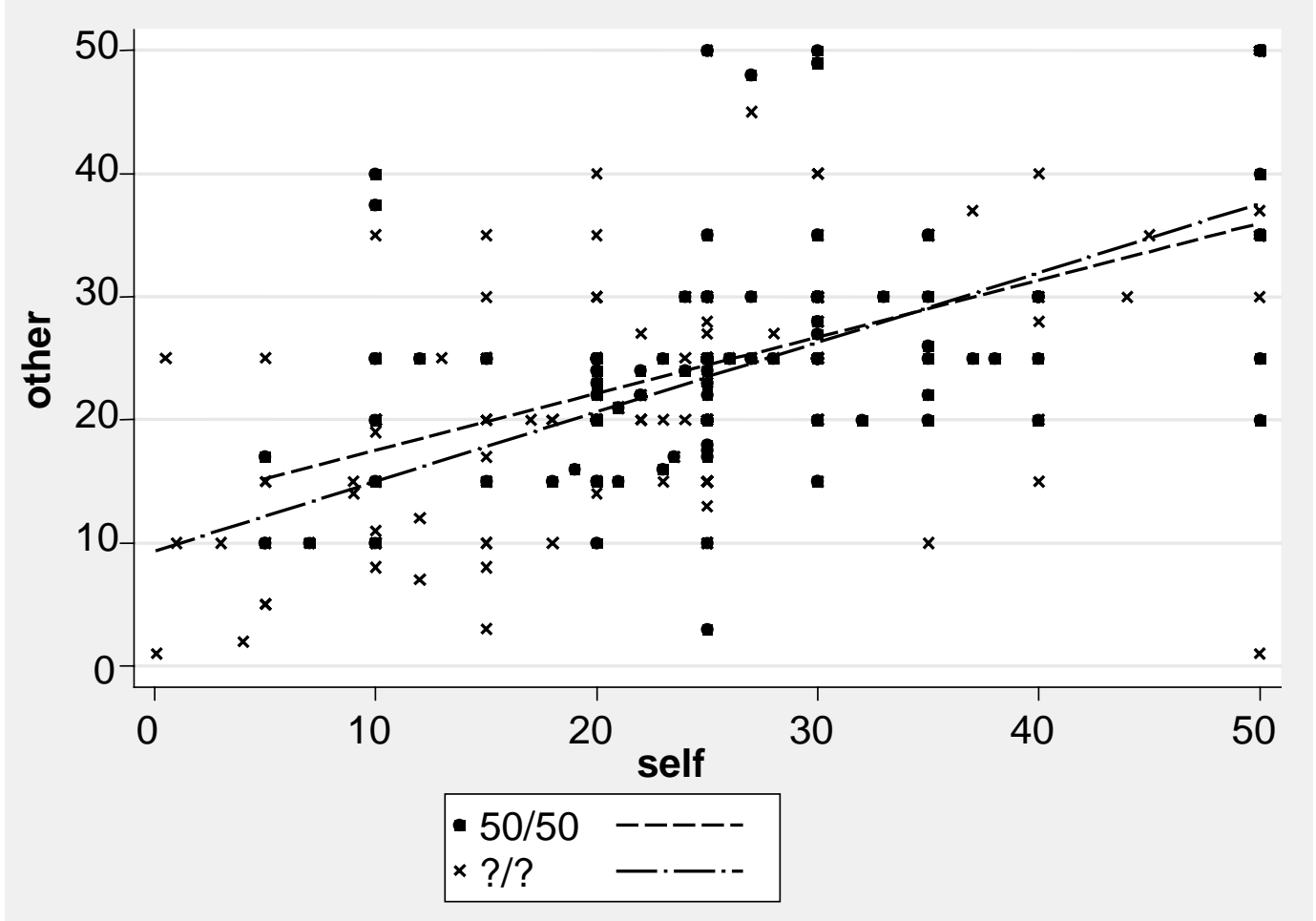


Appendix E: Lotteries plot

Figure E.1: Plot of the combined lotteries (questionnaire) and regression lines for 50/50and ?/?-probabilities.

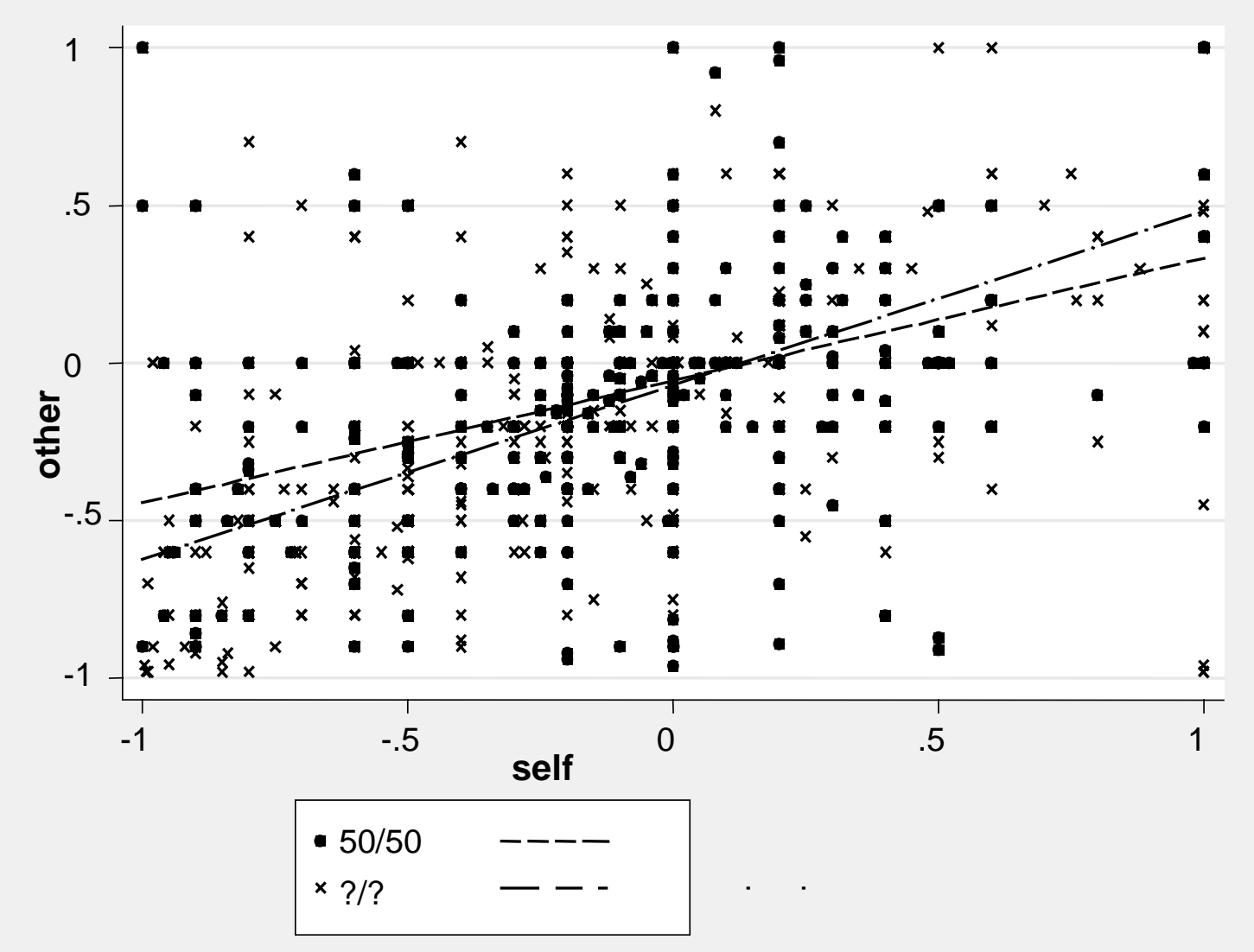




\section{Appendix F: Regression Results}

Table F.1: Regression Results Questionnaire: Regression of the predicted certainty equivalent on the own certainty equivalent (normalized by the mean certainty equivalent). Left side: Separate regressions for 2 Lotteries with 50/50-probabilities and 2 lotteries with ambiguous probabilities. Right side: Regressions with all 4 lotteries.

* indicates significance at the ten percent level, $* *$ indicates significance at the five percent level, *** indicates significance at the one percent level.

\begin{tabular}{|c|c|c|c|c|c|c|c|c|c|}
\hline & \multicolumn{4}{|c|}{ Predicted CE (Quest., each with 2 Lotteries) } & \multirow{2}{*}{\multicolumn{5}{|c|}{ Predicted CE (Questionnaire, each with all 4 Lotteries) }} \\
\hline & $50 / 50$ & $50 / 50$ & $? / ?$ & ?/? & & & & & \\
\hline$\overline{\text { Gender }}$ & & $\begin{array}{c}-0.0188 \\
(-0.50)\end{array}$ & & $\begin{array}{l}-0.1050 \\
(-2.06)^{\star \star}\end{array}$ & & & & & $\begin{array}{c}-0.0160 \\
(-0.79)\end{array}$ \\
\hline Age & & $\begin{array}{l}-0.0025 \\
(-0.31)\end{array}$ & & $\begin{array}{c}0.0040 \\
(0.36)\end{array}$ & & & & & $\begin{array}{l}-0.0020 \\
(-0.45)\end{array}$ \\
\hline Dummy Ambiguity & & & & & & $\begin{array}{l}0.0461 \\
(1.62)\end{array}$ & & $\begin{array}{l}0.0380 \\
(2.13)^{\star \star}\end{array}$ & $\begin{array}{l}0.0381 \\
(2.13)^{\star \star}\end{array}$ \\
\hline Own CE * Dummy Ambi & & & & & & & $\begin{array}{c}0.8680 \\
(22.45)^{\star \star \star}\end{array}$ & $\begin{array}{c}0.8663 \\
(22.53)^{\star \star \star}\end{array}$ & $\begin{array}{c}0.8637 \\
(22.31)^{\star \star \star}\end{array}$ \\
\hline Own CE & $\begin{array}{c}0.4172 \\
(6.39)^{\star \star \star}\end{array}$ & $\begin{array}{c}0.4153 \\
(6.32)^{\star \star \star}\end{array}$ & $\begin{array}{c}0.6695 \\
(14.91)^{\star \star \star}\end{array}$ & $\begin{array}{c}0.6595 \\
(14.64)^{\star \star \star}\end{array}$ & $\begin{array}{c}0.6181 \\
(17.34)^{\star \star \star}\end{array}$ & $\begin{array}{c}0.6181 \\
(17.38)^{\star \star \star}\end{array}$ & $\begin{array}{c}0.1554 \\
(5.09)^{\star \star \star}\end{array}$ & $\begin{array}{c}0.1563 \\
(5.15)^{\star \star \star}\end{array}$ & $\begin{array}{c}0.1570 \\
(5.16)^{\star \star \star}\end{array}$ \\
\hline Constant & $\begin{array}{l}-0.0368 \\
(-2.21)^{\star \star}\end{array}$ & $\begin{array}{c}0.0382 \\
(0.19)\end{array}$ & $\begin{array}{c}0.0092 \\
(0.41)\end{array}$ & $\begin{array}{c}-0.0116 \\
(-0.04)\end{array}$ & $\begin{array}{c}-0.0138 \\
(-0.97)\end{array}$ & $\begin{array}{l}-0.0368 \\
(-1.83)^{\star}\end{array}$ & $\begin{array}{c}-0.0178 \\
(-1.98)^{\star \star}\end{array}$ & $\begin{array}{c}-0.0368 \\
(-2.91)^{\star \star \star}\end{array}$ & $\begin{array}{c}0.0227 \\
(0.21)\end{array}$ \\
\hline $\mathbf{N}$ & 168 & 168 & 168 & 168 & 336 & 336 & 336 & 336 & 336 \\
\hline Adjusted R-squared & 0.1925 & 0.1846 & 0.5700 & 0.5757 & 0.4721 & 0.4747 & 0.7895 & 0.7917 & 0.7910 \\
\hline
\end{tabular}

Table F.2: Regression Results Lab: Regression of the predicted certainty equivalent on the own certainty equivalent (normalized by the mean certainty equivalent). Left side: Separate regressions for 3 Lotteries with 50/50-probabilities and 3 lotteries with ambiguous probabilities. Right side: Regressions with all 6 lotteries.

* indicates significance at the ten percent level,** indicates significance at the five percent level, *** indicates significance at the one percent level.

\begin{tabular}{|c|c|c|c|c|c|c|c|c|c|}
\hline & \multicolumn{4}{|c|}{ Predicted CE (Lab, each with 3 Lotteries) } & \multicolumn{5}{|c|}{ Predicted CE (Lab, each with all 6 Lotteries) } \\
\hline & $50 / 50$ & $50 / 50$ & ?/? & ?/? & & & & & \\
\hline Gender & & $\begin{array}{l}-0.0698 \\
(-2.55)^{\star \star}\end{array}$ & & $\begin{array}{c}-0.0171 \\
(-0.44)\end{array}$ & & & & & $\begin{array}{l}-0.0434 \\
(-1.83)^{\star}\end{array}$ \\
\hline Age & & $\begin{array}{c}0.0077 \\
(1.23)\end{array}$ & & $\begin{array}{l}0.0187 \\
(2.09)^{\star \star}\end{array}$ & & & & & $\begin{array}{l}0.0131 \\
(2.41)^{\star \star}\end{array}$ \\
\hline Semester & & $\begin{array}{c}-0.0092 \\
(-1.60)\end{array}$ & & $\begin{array}{l}-0.0147 \\
(-1.81)^{\star}\end{array}$ & & & & & $\begin{array}{l}-0.0120 \\
(-2.40)^{\star \star}\end{array}$ \\
\hline Knowledge & & $\begin{array}{l}-0.0203 \\
(-1.74)^{\star}\end{array}$ & & $\begin{array}{c}-0.0161 \\
(-0.97)\end{array}$ & & & & & $\begin{array}{l}-0.0182 \\
(-1.80)^{\star}\end{array}$ \\
\hline Ordering & & $\begin{array}{l}-0.0466 \\
(-1.91)^{\star}\end{array}$ & & $\begin{array}{c}-0.0995 \\
(-2.87)^{\star \star \star}\end{array}$ & & & & & $\begin{array}{c}-0.0730 \\
(-3.45)^{\star \star \star}\end{array}$ \\
\hline Dummy Ambiguity & & & & & & $\begin{array}{l}0.0425 \\
(2.00)^{\star \star}\end{array}$ & & $\begin{array}{l}0.0425 \\
(2.01)^{\star \star}\end{array}$ & $\begin{array}{c}0.0425 \\
(2.03)^{\star \star}\end{array}$ \\
\hline Own CE * Dummy Ambi & & & & & & & $\begin{array}{c}0.1895 \\
(3.92)^{\star \star \star}\end{array}$ & $\begin{array}{c}0.1896 \\
(3.92)^{\star \star \star}\end{array}$ & $\begin{array}{c}0.1858 \\
(3.85)^{\star \star \star}\end{array}$ \\
\hline Own CE & $\begin{array}{c}0.3609 \\
(11.03)^{\star \star \star}\end{array}$ & $\begin{array}{c}0.3697 \\
(11.28)^{\star \star \star}\end{array}$ & $\begin{array}{c}0.5504 \\
(17.73)^{\star \star \star}\end{array}$ & $\begin{array}{c}0.5599 \\
(17.95)^{\star \star \star}\end{array}$ & $\begin{array}{c}0.4920 \\
(21.88)^{\star \star \star}\end{array}$ & $\begin{array}{c}0.4920 \\
(21.91)^{\star \star \star}\end{array}$ & $\begin{array}{c}0.3609 \\
(8.97)^{\star \star \star}\end{array}$ & $\begin{array}{c}0.3609 \\
(8.98)^{\star \star \star}\end{array}$ & $\begin{array}{c}0.3703 \\
(9.23)^{\star \star \star}\end{array}$ \\
\hline Constant & $\begin{array}{l}-0.0271 \\
(-2.23)^{\star \star}\end{array}$ & $\begin{array}{c}-0.1603 \\
(-1.21) \\
\end{array}$ & $\begin{array}{l}0.0154 \\
(-0.89) \\
\end{array}$ & $\begin{array}{c}-0.2523 \\
(-1.34) \\
\end{array}$ & $\begin{array}{c}-0.0058 \\
(-0.55) \\
\end{array}$ & $\begin{array}{l}-0.0271 \\
(-1.80)^{\star}\end{array}$ & $\begin{array}{c}-0.0058 \\
(-0.55) \\
\end{array}$ & $\begin{array}{l}-0.0271 \\
(-1.82)^{\star} \\
\end{array}$ & $\begin{array}{l}-0.2263 \\
(-1.96)^{\star \star}\end{array}$ \\
\hline $\mathbf{N}$ & 597 & 597 & 597 & 597 & 1194 & 1194 & 1194 & 1194 & 1194 \\
\hline Adjusted R-squared & 0.1684 & 0.1790 & 0.3447 & 0.3527 & 0.2860 & 0.2878 & 0.2945 & 0.2963 & 0.3055 \\
\hline
\end{tabular}


Figure G.1: Histogram of stated certainty equivalents for the ?/?-lottery $(1000,0)$, vertical lines indicate the 90 percent interval (50-800).

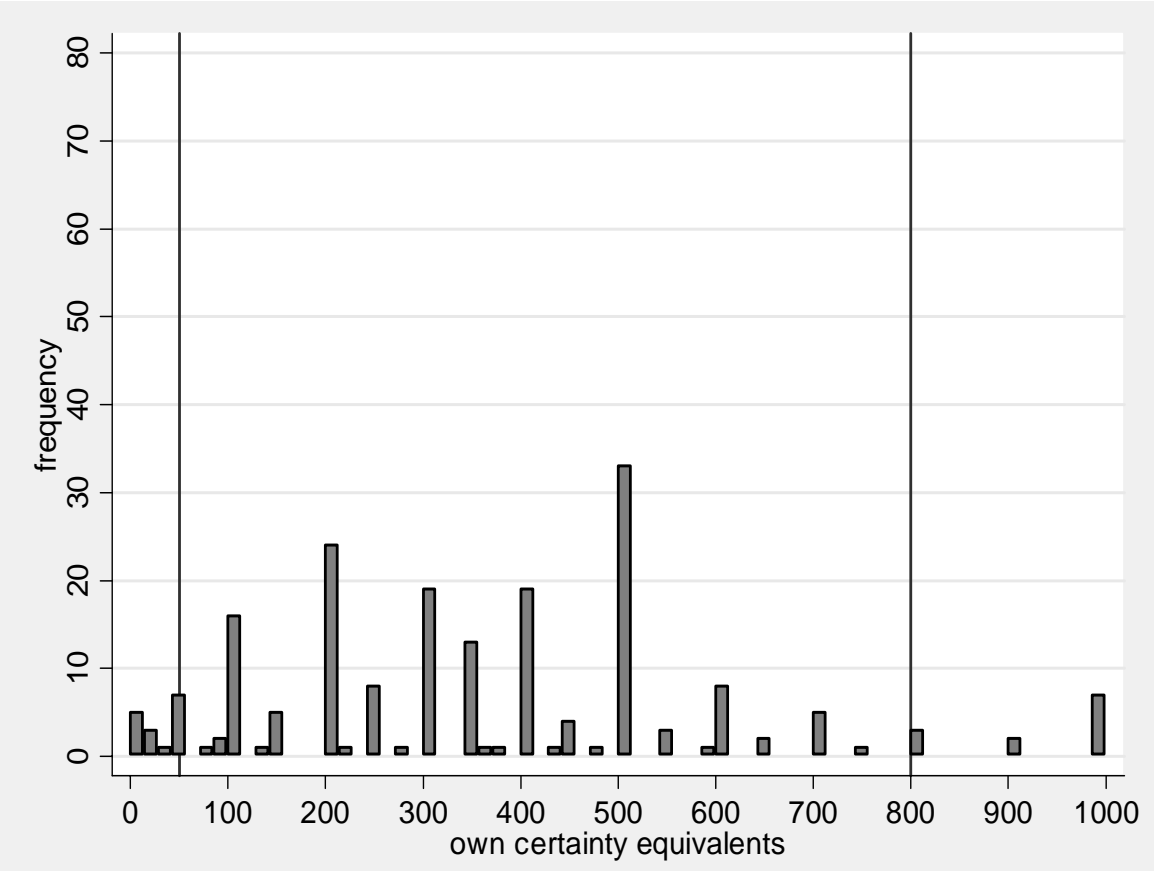

Figure G.2: Predicted 90 percent intervals for the ?/?-lottery (1000,0), intervals are ordered by the size of the own certainty equivalents (x-axis from low to high). The true 90 percent interval (50-800) is indicated by horizontal lines.

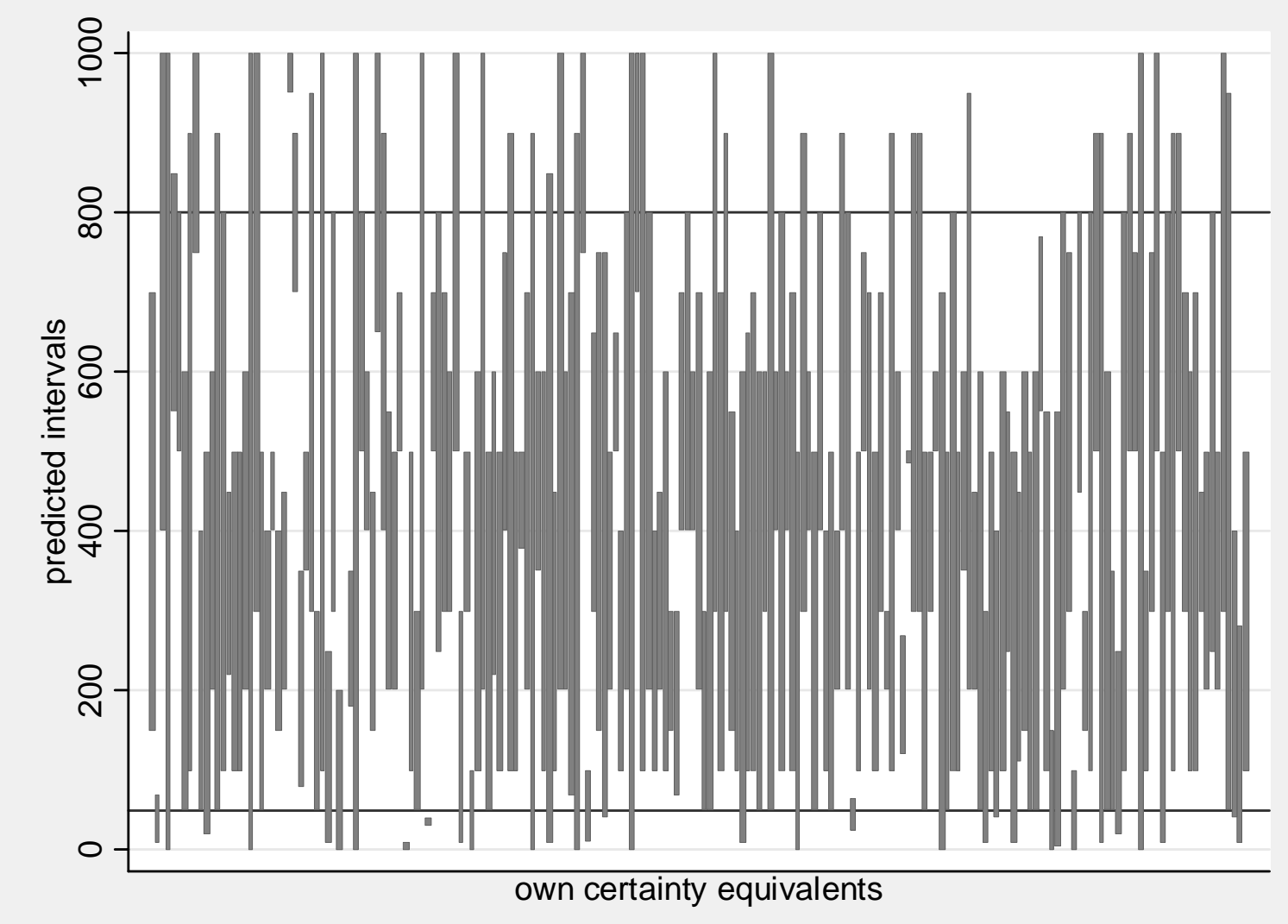


Figure G.3: Histogram of stated certainty equivalents for the $50 / 50$-lottery $(200,0)$, vertical lines indicate the 90 percent interval (25-150).

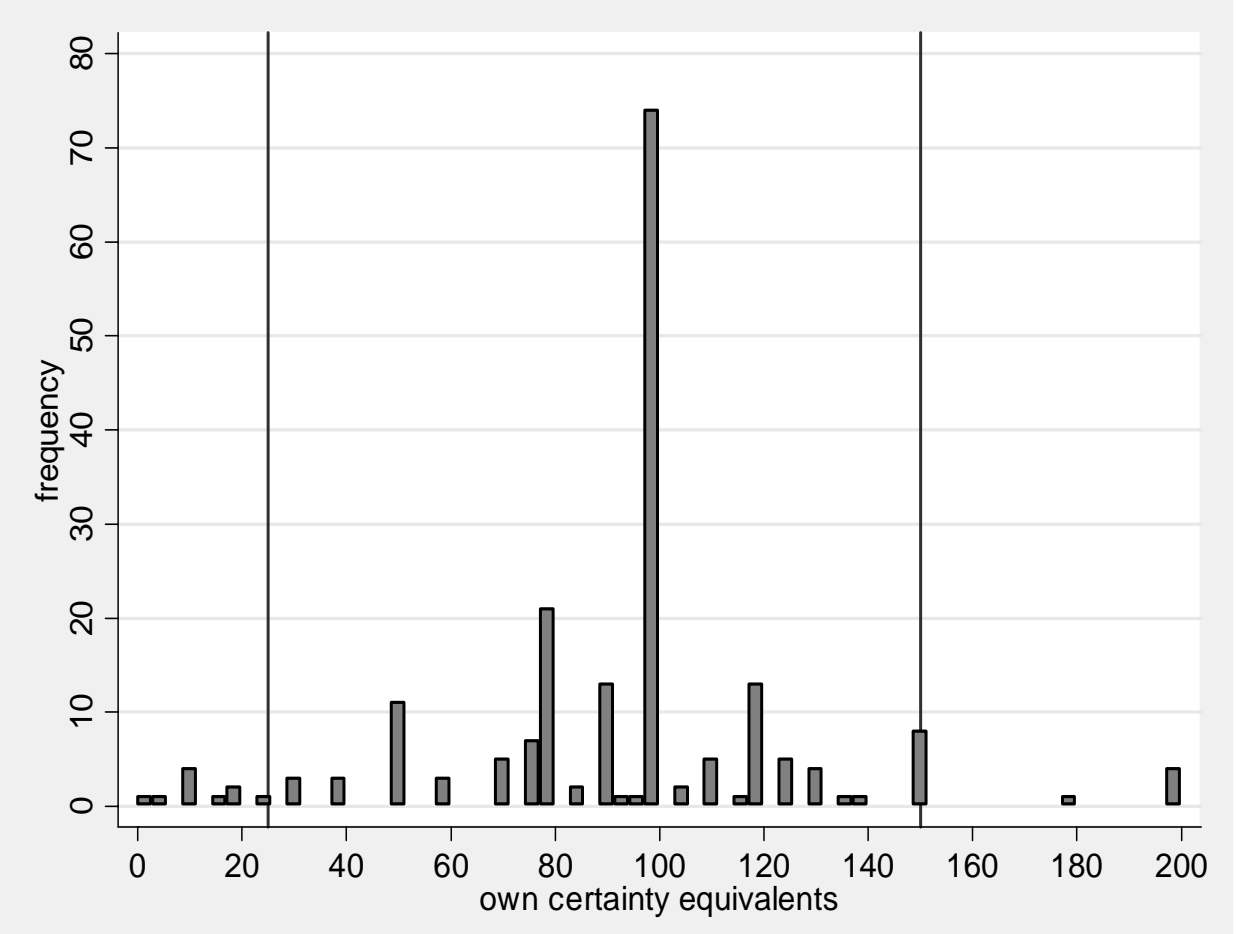

Figure G.4: Predicted 90 percent intervals for the 50/50-lottery (200,0), intervals are ordered by the size of the own certainty equivalents (x-axis from low to high). The true 90 percent interval (25-150) is indicated by horizontal lines.

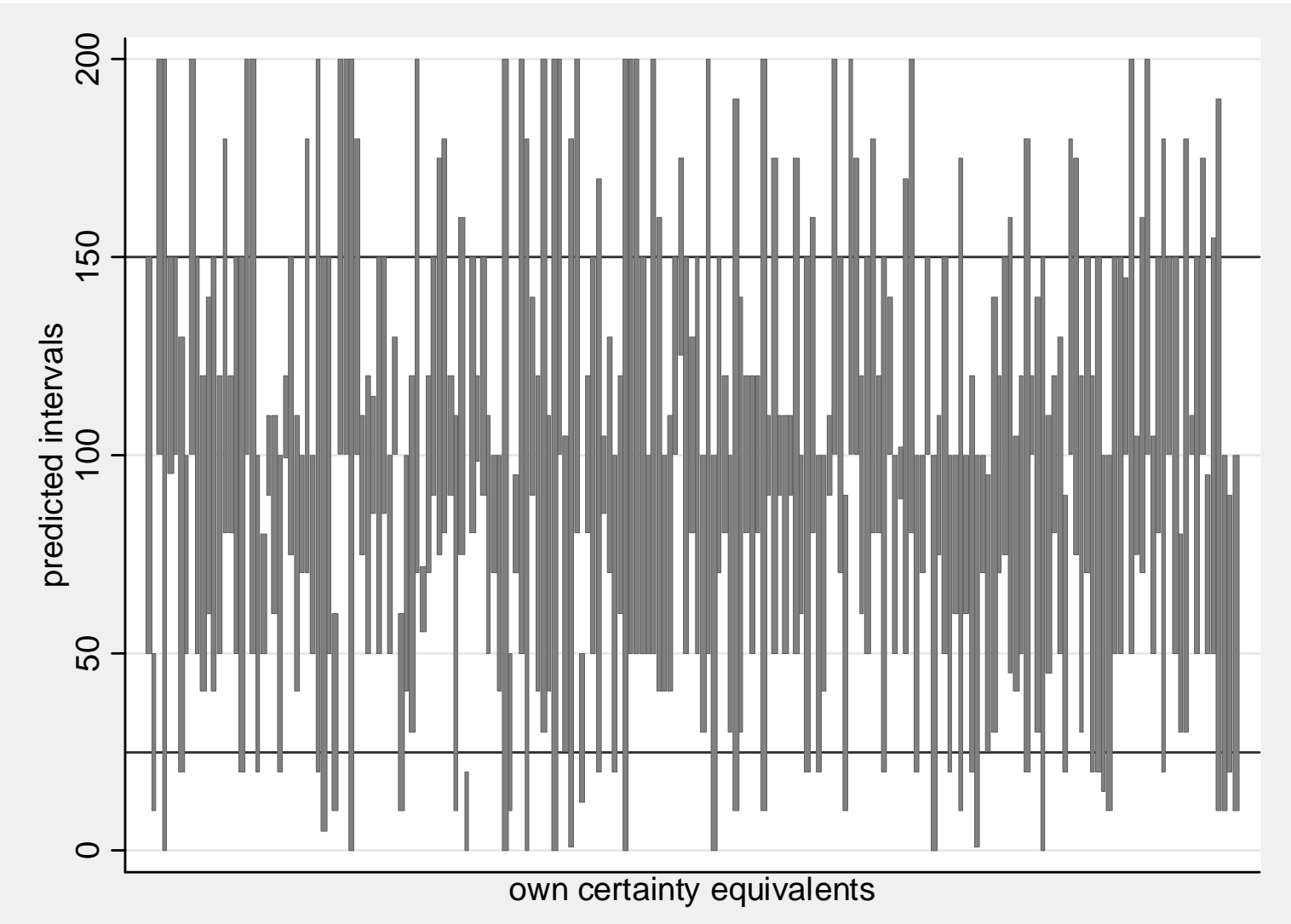


Figure G.5: Histogram of stated certainty equivalents for the ?/?-lottery $(200,0)$, vertical lines indicate the 90 percent interval (10-188).

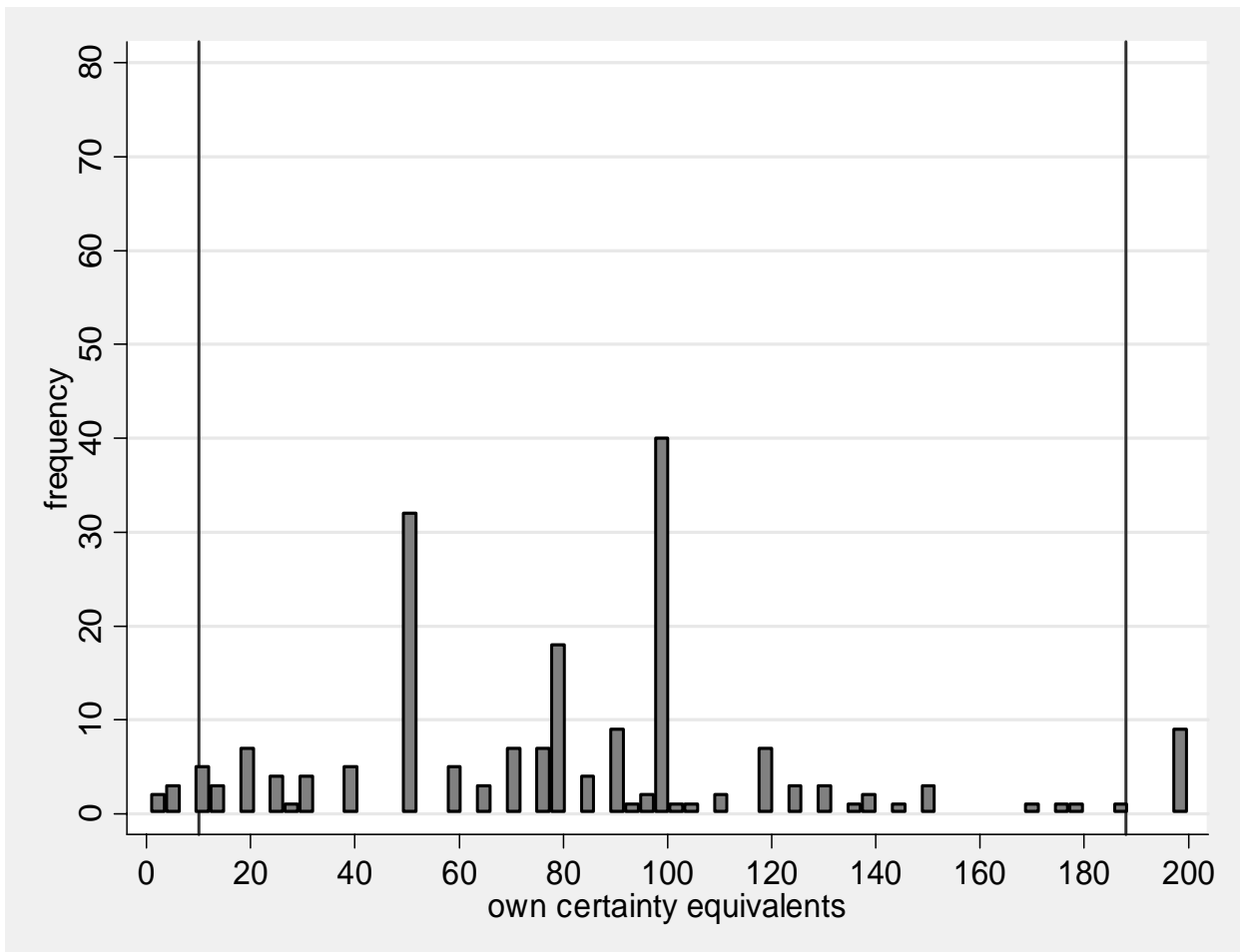

Figure G.6: Predicted 90 percent intervals for the ?/?-lottery $(200,0)$, intervals are ordered by the size of the own certainty equivalents (x-axis from low to high). The true 90 percent interval (10-188) is indicated by horizontal lines.

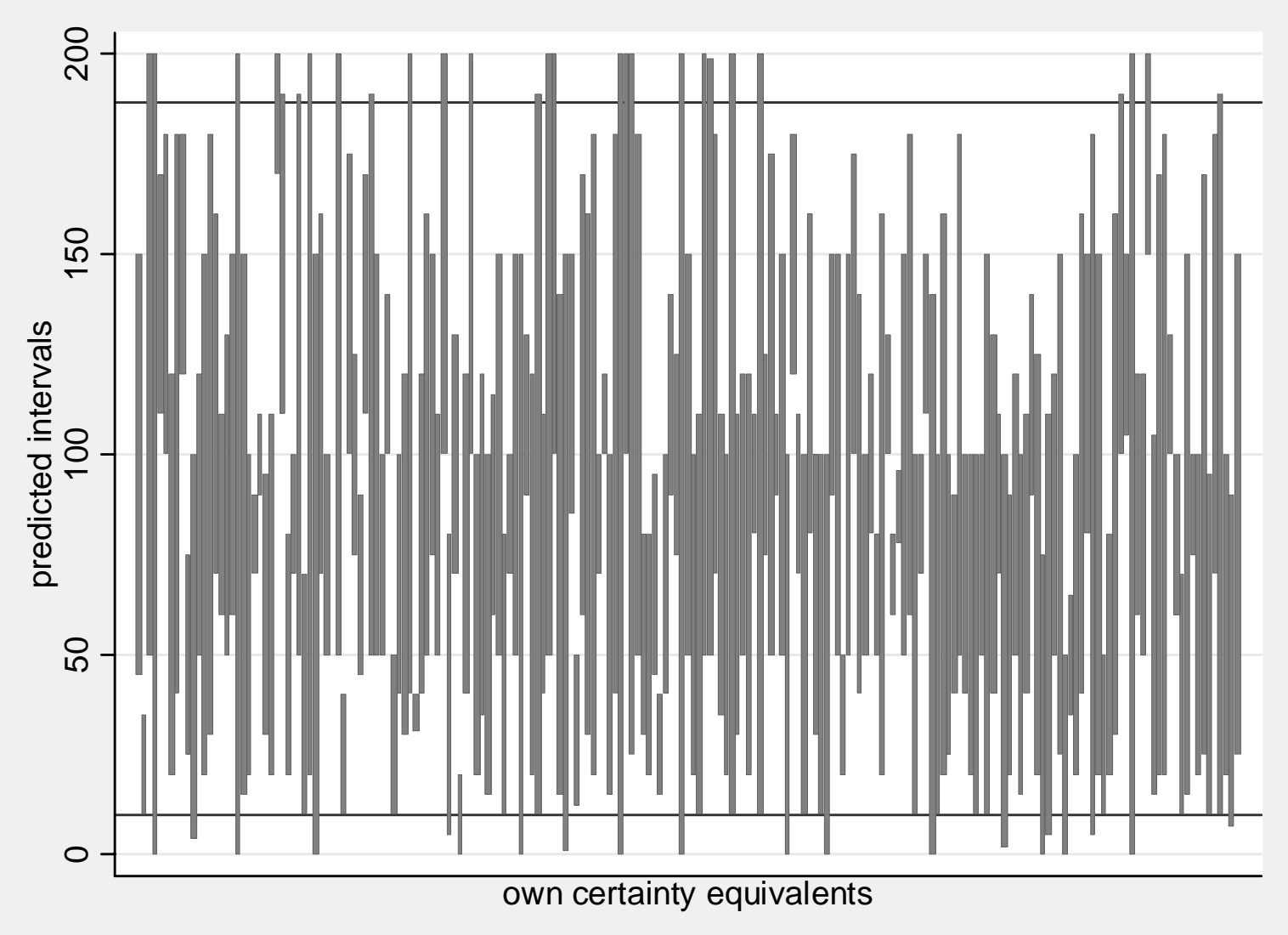


Figure G.7: Histogram of stated certainty equivalents for the $50 / 50$-lottery $(50,0)$, vertical lines indicate the 90 percent interval (10-40).

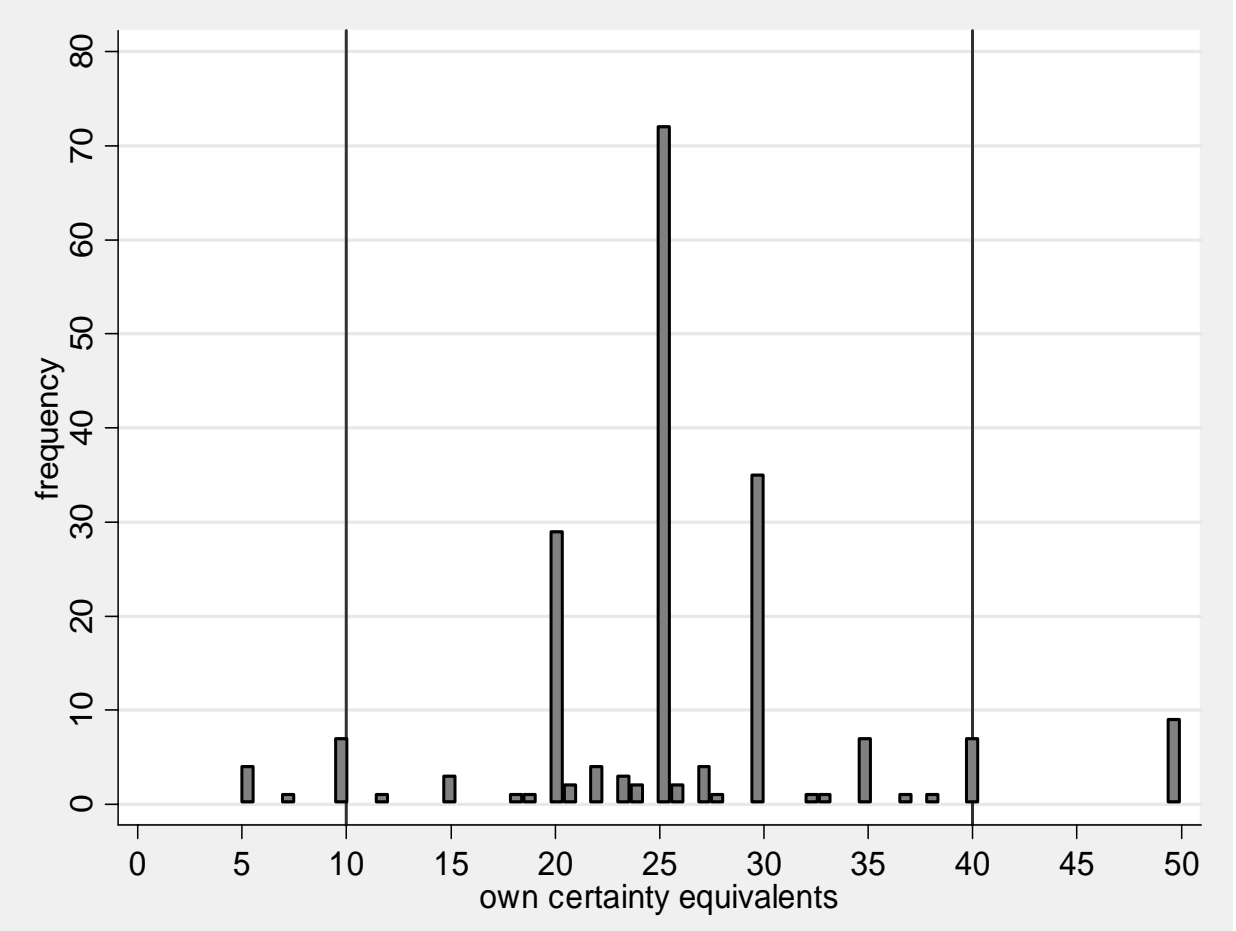

Figure G.8: Predicted 90 percent intervals for the 50/50-lottery (50,0), intervals are ordered by the size of the own certainty equivalents (x-axis from low to high). The true 90 percent interval (10-40) is indicated by horizontal lines.

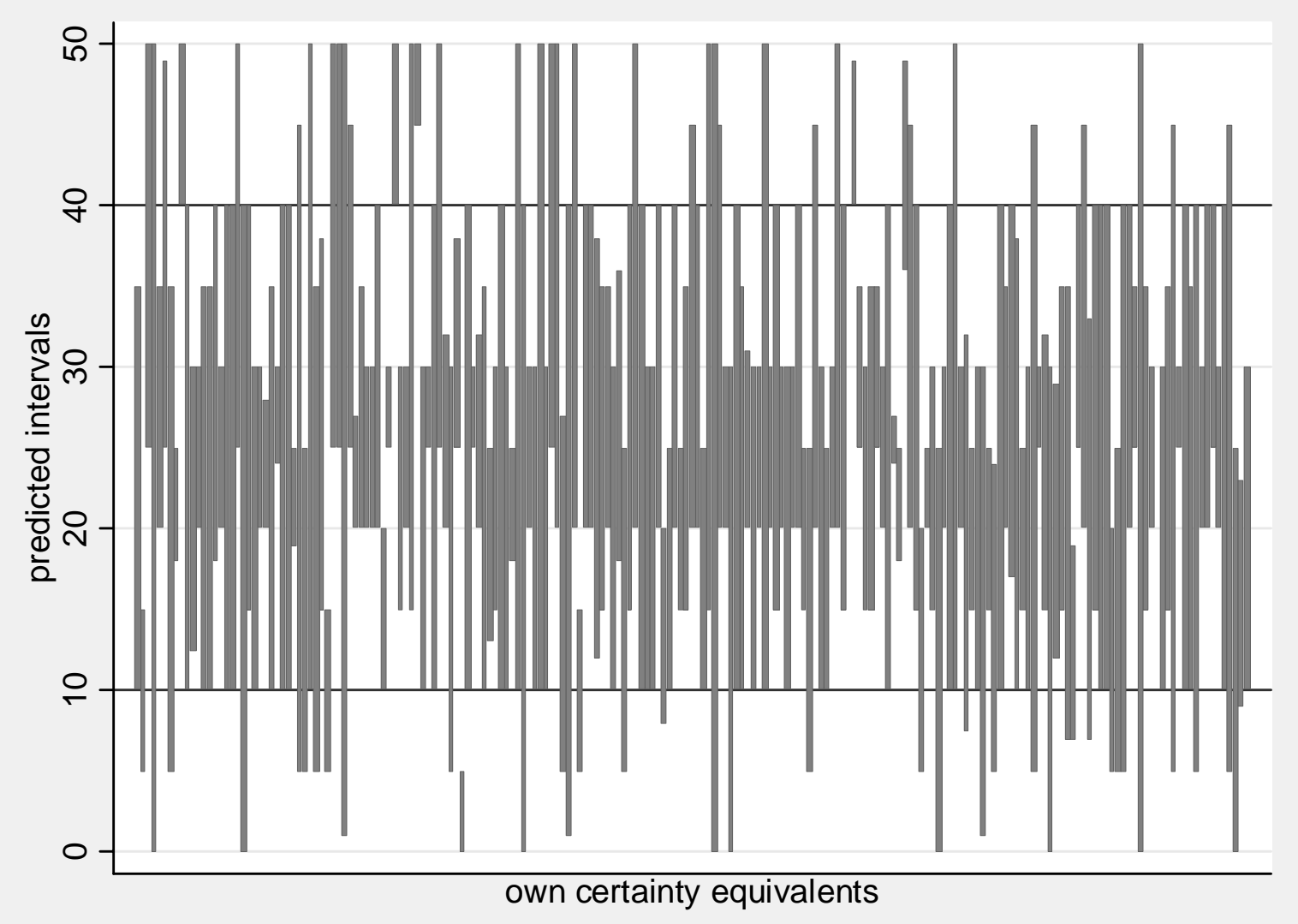


Figure G.9: Histogram of stated certainty equivalents for the ?/?-lottery $(50,0)$, vertical lines indicate the 90 percent interval (5-50).

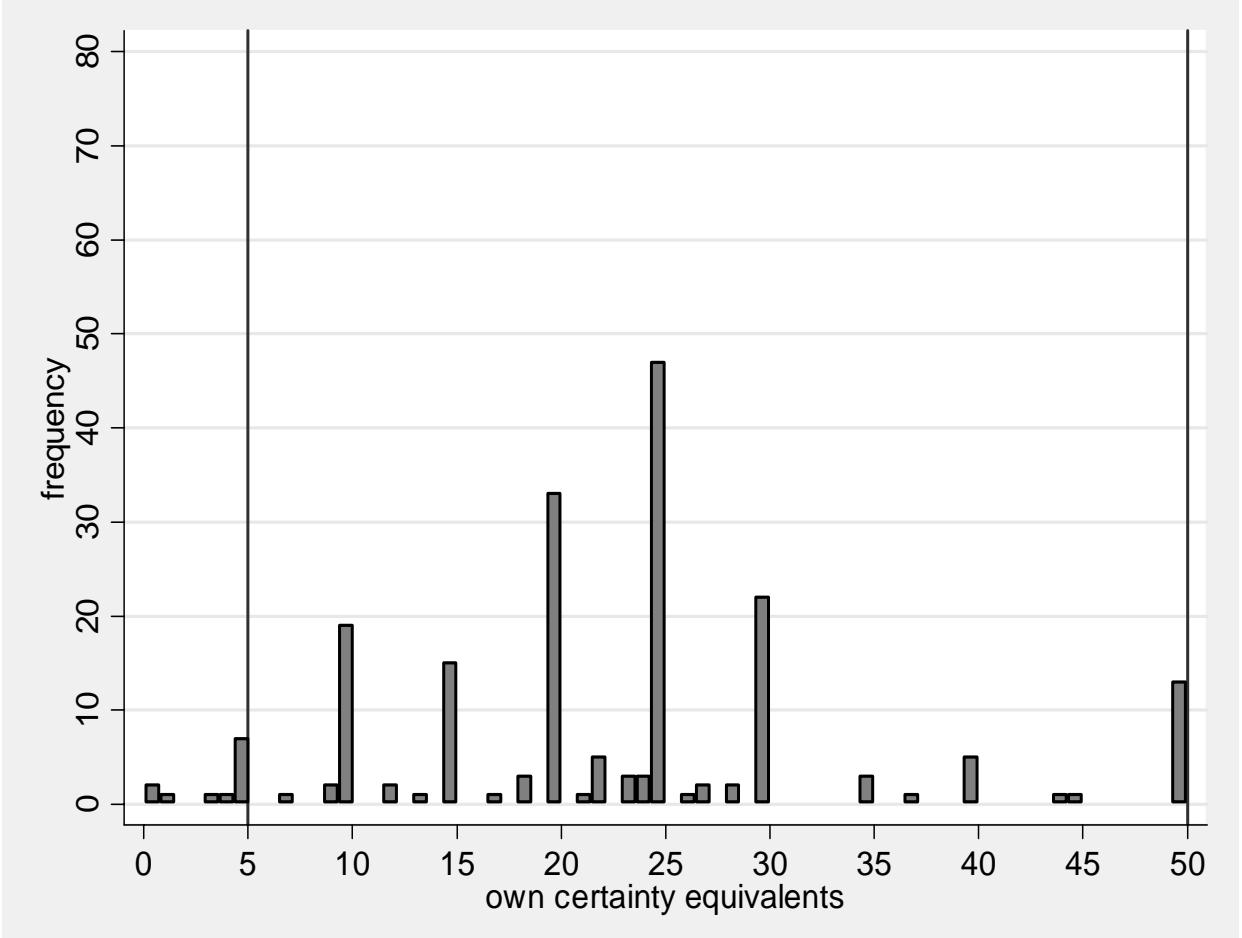

Figure G.10: Predicted 90 percent intervals for the ?/?-lottery $(50,0)$, intervals are ordered by the size of the own certainty equivalents (x-axis from low to high). The true 90 percent interval (5-50) is indicated by horizontal lines.

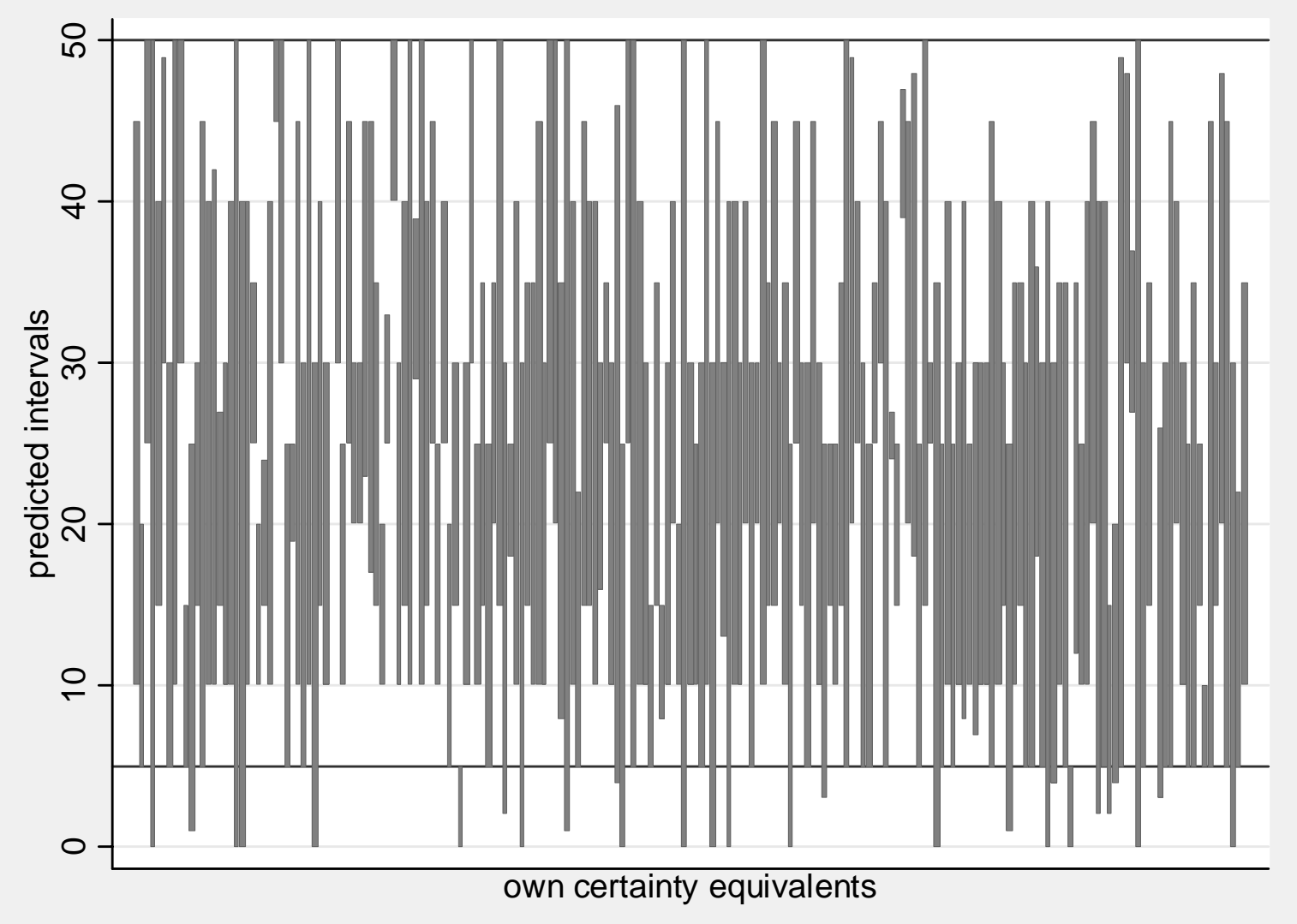




\begin{tabular}{|c|c|c|}
\hline Nr. & Author & Title \\
\hline $07-48$ & Clemens Kroneberg & $\begin{array}{l}\text { Wertrationalität und das Modell der } \\
\text { Frame-Selektion }\end{array}$ \\
\hline $07-47$ & $\begin{array}{l}\text { Dirk Simons } \\
\text { Nicole Zein }\end{array}$ & Audit market segmentation and audit quality \\
\hline $07-46$ & $\begin{array}{l}\text { Sina Borgsen } \\
\text { Martin Weber }\end{array}$ & $\begin{array}{l}\text { False Consensus and the Role of Ambiguity in } \\
\text { Predictions of Othersí Risky Preferences }\end{array}$ \\
\hline $07-45$ & $\begin{array}{l}\text { Martin Weber } \\
\text { Frank Welfens }\end{array}$ & $\begin{array}{l}\text { An Individual Level Analysis of the Disposition } \\
\text { Effect: Empirical and Experimental Evidence }\end{array}$ \\
\hline $07-44$ & $\begin{array}{l}\text { Martin Weber } \\
\text { Frank Welfens }\end{array}$ & $\begin{array}{l}\text { The Repurchase Behavior of Individual Investors: } \\
\text { An Experimental Investigation }\end{array}$ \\
\hline $07-43$ & $\begin{array}{l}\text { Manel Baucells } \\
\text { Martin Weber } \\
\text { Frank Welfens }\end{array}$ & $\begin{array}{l}\text { Reference Point Formation Over Time: A } \\
\text { Weighting Function Approach }\end{array}$ \\
\hline $07-42$ & $\begin{array}{l}\text { Martin Weber } \\
\text { Frank Welfens }\end{array}$ & $\begin{array}{l}\text { How do Markets React to Fundamental Shocks? An } \\
\text { Experimental Analysis on Underreaction and } \\
\text { Momentum }\end{array}$ \\
\hline $07-41$ & $\begin{array}{l}\text { Ernst Maug } \\
\text { Ingolf Dittmann }\end{array}$ & $\begin{array}{l}\text { Lower Salaries and No Options: The Optimal } \\
\text { Structure of Executive Pay }\end{array}$ \\
\hline $07-40$ & $\begin{array}{l}\text { Ernst Maug } \\
\text { Ingolf Dittmann } \\
\text { Christoph Schneider }\end{array}$ & Bankers and the Performance of German Firms \\
\hline 07-39 & $\begin{array}{l}\text { Michael Ebert } \\
\text { Nicole Zein }\end{array}$ & $\begin{array}{l}\text { Wertorientierte Vergütung des Aufsichtsrats - } \\
\text { Auswirkungen auf den Unternehmenswert }\end{array}$ \\
\hline $07-38$ & $\begin{array}{l}\text { Ingolf Dittmann } \\
\text { Ernst Maug } \\
\text { Christoph Schneider }\end{array}$ & $\begin{array}{l}\text { How Preussag became TUI: Kissing too Many } \\
\text { Toads Can Make You a Toad }\end{array}$ \\
\hline $07-37$ & $\begin{array}{l}\text { Ingolf Dittmann } \\
\text { Ernst Maug }\end{array}$ & $\begin{array}{l}\text { Valuation Biases, Error Measures, and the } \\
\text { Conglomerate Discount }\end{array}$ \\
\hline $07-36$ & $\begin{array}{l}\text { Ingolf Dittmann } \\
\text { Ernst Maug } \\
\text { Oliver Spalt }\end{array}$ & $\begin{array}{l}\text { Executive Stock Options when Managers are } \\
\text { Loss-Averse }\end{array}$ \\
\hline
\end{tabular}




\begin{tabular}{|c|c|c|}
\hline Nr. & Author & Title \\
\hline $07-35$ & $\begin{array}{l}\text { Ernst Maug } \\
\text { Kristian Rydqvist }\end{array}$ & $\begin{array}{l}\text { Do Shareholders Vote Strategically? Voting } \\
\text { Behavior, Proposal Screening, and Majority Rules }\end{array}$ \\
\hline $07-34$ & $\begin{array}{l}\text { Ernst Maug } \\
\text { Abraham Ackerman }\end{array}$ & $\begin{array}{l}\text { Insider Trading Legislation and Acquisition } \\
\text { Announcements: Do Laws Matter? }\end{array}$ \\
\hline $07-33$ & Dirk Simons & Independence, low balling and learning effects \\
\hline 07-32 & $\begin{array}{l}\text { Rainer Greifeneder } \\
\text { Herbert Bless }\end{array}$ & $\begin{array}{l}\text { Relying on accessible content versus accessibility } \\
\text { experiences: The case of processing capacity }\end{array}$ \\
\hline 07-31 & $\begin{array}{l}\text { Rainer Greifeneder } \\
\text { Herbert Bless }\end{array}$ & $\begin{array}{l}\text { Depression and reliance on ease-of-retrieval } \\
\text { experiences }\end{array}$ \\
\hline $07-30$ & $\begin{array}{l}\text { Florian Heiss } \\
\text { Axel Börsch-Supan } \\
\text { Michael Hurd } \\
\text { David Wise }\end{array}$ & $\begin{array}{l}\text { Pathways to Disability: Predicting Health } \\
\text { Trajectories }\end{array}$ \\
\hline 07-29 & $\begin{array}{l}\text { Axel Börsch-Supan } \\
\text { Alexander Ludwig } \\
\text { Mathias Sommer }\end{array}$ & Aging and Asset Prices \\
\hline $07-28$ & Axel Börsch-Supan & $\begin{array}{l}\text { GLOBAL AGING - Issues, Answers, More } \\
\text { Questions }\end{array}$ \\
\hline $07-27$ & Axel Börsch-Supan & MIND THE GAP: \\
\hline $07-26$ & Axel Börsch-Supan & Labor market effects of population aging \\
\hline $07-25$ & Axel Börsch-Supan & Rational Pension Reform \\
\hline $07-24$ & Axel Börsch-Supan & $\begin{array}{l}\text { European welfare state regimes and their generosity } \\
\text { towards the elderly }\end{array}$ \\
\hline $07-23$ & Axel Börsch-Supan & Work Disability, Health, and Incentive Effects \\
\hline $07-22$ & $\begin{array}{l}\text { Tobias Greitemeyer } \\
\text { Rainer Greifeneder }\end{array}$ & $\begin{array}{l}\text { Why the Euro looked like a price booster: } \\
\text { Differential perception of increasing versus } \\
\text { decreasing prices }\end{array}$ \\
\hline
\end{tabular}




\begin{tabular}{lll}
\hline Nr. & Author & Title
\end{tabular}

07-21 Patrick A. Müller Rainer Greifeneder Dagmar Stahlberg Herbert Bless

07-20 Volker Stocké

07-19 Jürgen Eichberger David Kelsey

Burkhard Schipper

07-18 Jürgen Eichberger Willy Spanjers

07-17 Patrick A. Müller Jana Janßen Dominique Jarzina

07-16 Patrick A. Müller Dagmar Stahlberg

07-15 Axel Börsch-Supan Anette Reil-Held

Daniel Schunk

07-14 Alexander Ludwig Dirk Krüger Axel Börsch-Supan

07-13 Melanie Lührmann

07-12 Axel Börsch-Supan Anette Reil-Held Christina Wilke

07-11 Alexander Ludwig Dirk Krüger
Relying on accessibility experiences in procedural fairness judgments

The Motive for Status Maintenance and Inequality in Educational Decisions. Which of the Parents Defines the Reference Point?

Ambiguity and Social Interaction

Liquidity and Ambiguity: Banks or Asset Markets?

Applicantsí reactions to selection procedures ñ Prediction uncertainty as a moderator of the relationship between procedural fairness and organizational attractiveness

The Role of Surprise in Hindsight Bias ñ A Metacognitive Model of Reduced and Reversed Hindsight Bias

Das Sparverhalten deutscher Haushalte: Erste Erfahrungen mit der Riester-Rente

Demographic Change, Relative Factor Prices, International Capital Flows, and their Differential Effects on the Welfare of Generations

Consumer Expenditures and Home Production at Retirement: New Evidence from Germany

Zur Sozialversicherungsfreiheit der Entgeltumwandlung

On the Consequences of Demographic Change for Rates of Returns to Capital, and the Distribution of Wealth and Welfare 